\title{
Universiteit
}

Leiden

The Netherlands

\section{Much more than trade: the common commercial policy in a global context}

Larik, J.E.; Evans, M.; Koutrakos, P.

\section{Citation}

Larik, J. E. (2011). Much more than trade: the common commercial policy in a global context. In M. Evans \& P. Koutrakos (Eds.), Beyond the Established Legal Orders: Policy Interconnections between the EU and the Rest of the World (pp. 13-46). Hart Publishing. Retrieved from https://hdl.handle.net/1887/139048

Version: $\quad$ Not Applicable (or Unknown)

License: $\quad$ Leiden University Non-exclusive license

Downloaded from: $\quad$ https://hdl.handle.net/1887/139048

Note: To cite this publication please use the final published version (if applicable). 
Part One

Economic Governance 



\title{
Much More Than Trade: The Common Commercial Policy in a Global Context
}

\author{
JORIS LARIK ${ }^{1}$
}

\section{INTRODUCTION}

I

N ASSESSING THE law and policy interconnections between the European Union (EU) and the rest of the world, trade appears as an appropriate point of departure. As the European Commission's Directorate-General for Trade (DG Trade) boldly puts it in one of their brochures, 'Europe's single most important contact with the world beyond its borders is through trade.'2 Being the world's largest exporter of goods and services, and being the largest export market for over a hundred countries, DG Trade stresses that trade is 'at the centre of Europe's place in the world. ${ }^{3}$ This is not simply a case of institutional self-assertion but an observation echoed in the academic community. For Cartou and others, for a long time the Union's Common Commercial Policy (CCP) constituted 'l'essentiel't of the EU's external relations. For Eeckhout, the CCP still 'remains the centrepiece of the EU's external policies. ${ }^{5}$ Similarly, Cremona underlines that it is 'as an active player in the global market that the Union has played its first and still most-high profile role.6 For Meunier and Nicolaïdis, trade is nothing less than 'the EU's raison d'être.' But they also stress that the Union is not simply 'a formidable power in

\footnotetext{
1 The author expresses his gratitude to Marise Cremona, Panos Koutrakos, Malcolm Evans and David Kleimann for their valuable comments on earlier drafts, as well as to the various officials of the European Commission's Directorate-General for Trade and the Trade Team of the Commission Legal Service, who kindly provided extensive information in the course of writing this chapter. Of course, any shortcomings remain the author's alone.

2 European Commission, DG Trade, What is Europe's Trade Policy?, April 2009, at 2.

3 Ibid.

4 L Cartou, J-L Clergerie, A Gruber and P Rambaud, L'Union européenne, 4th edn (Paris, Dalloz, 2002), at 684 .

5 P Eeckhout, External Relations of the European Union: Legal and Constitutional Foundations (Oxford, Oxford University Press, 2004), at 347.

6 M Cremona, 'The Union as a Global Actor: Roles Models and Identity' (2004) 41 CML Rev 553, at 555 .

7 S Meunier and K Nicolaïdis, 'The European Union as a Trade Power' in C Hill and M Smith (eds), International Relations and the European Union (Oxford, Oxford University Press, 2005), at 248.
} 
trade' 8 but also 'a power through trade.' 9 It is not only a 'laboratory' and 'dynamic experiment' for itself, but also a 'magnet' for those surrounding it and 'a model' for other regions as well as for the system as a whole, ${ }^{10}$ turning the mere power of attraction into actual rapprochement or transformation.

The latest leap in this dynamic experiment is the entry into force of the Lisbon Treaty on 1 December 2009, ${ }^{11}$ bringing to a close the reform effort started with the-eventually unsuccessful-Constitutional Treaty project launched at the Laeken Council in 2001. ${ }^{12}$ As from that day, the Maastricht pillar structure has legally vanished. So has the European Community, having been absorbed by the single legal personality of the European Union. ${ }^{13}$

The new institutional structure also brought important changes in the area of trade. ${ }^{14}$ Most significantly, the entire CCP it is now an area of exclusive Union competence. ${ }^{15}$ This is the way it started out in the Treaty of Rome and was confirmed by the European Court of Justice (ECJ) in Opinion 1/75 when this concerned only trade in goods. ${ }^{16}$ But with the emergence of a deeper trade agenda involving services and intellectual property rights in the Uruguay Round, the ECJ ruled that in the latter two areas, competence was partly shared with the Member States. ${ }^{17}$ This was then recognised in the Amsterdam Treaty by convoluted provisions aimed at carving out reservoirs of shared competence, which were later in part rolled back in the Nice Treaty. ${ }^{18}$ Under Lisbon, these have been removed, while unanimity in the Council has been retained for the conclusion of agreements in certain sensitive areas such as cultural, education and health services. ${ }^{19}$

8 Ibid, at 265 .

9 Ibid, at 266.

10 Cremona, above n 6, at 553-55.

11 Reference will be made throughout this chapter to the Treaties as amended by the Lisbon Treaty, ie to the Treaty on European Union (TEU) and the Treaty on the Functioning of the European Union (TFEU) as they are in force as of 1 December 2009.

12 For a discussion of this see, eg, G de Búrca, 'The EU on the Road from the Constitutional Treaty to the Lisbon Treaty', Jean Monnet Working Paper 03/08 (New York, New York University School of Law, 2008).

13 Arts 1(3) and 47 TEU.

14 See E Pache, 'Organgefüge und Handlungsträger der EU nach Lissabon' in E Pache and F Schorkopf (eds), Die Europäische Union nach Lissabon: Beiträge zu Organisation, Außenbeziehungen und Stellung im Welthandelsrecht, Kolloquium aus Anlass des 70. Geburtstages von Professor Dr Meinhard Hilf (Baden-Baden, Nomos, 2009); P-C Müller-Graff, 'The common commercial policy enhanced by the Reform Treaty of Lisbon' in A Dashwood and M Maresceau (eds), Law and Practice of EU External Relations: Salient Features of a Changing Landscape (Cambridge, Cambridge University Press, 2008).

15 Art 3(1)(e) TEU.

16 Opinion 1/75 [1975] ECR 01355.

17 Opinion 1/94 [1995] ECR I-05267.

18 Ex Art 133 Treaty on establishing the European Community (TEC); for the changing scope of (then) Community competence, see Opinion 1/08 of 30 November 2009, nyr, paras 117-74. See also Eeckhout, above n 5, at 9-53; A Cebada Romero, La Organización Mundial del Comercio y la Unión Europea (Madrid, La Ley, 2002), at 253-65; and I Blázquez Navarro, Integración europea y diferencias comerciales en la OMC (Madrid, Marcial Pons, 2007), at 153-202.

19 Art 207(4) TFEU; for a detailed account of trade in the area of culture, see B de Witte, 'Trade in Culture: International Legal Regimes and EU Constitutional Values' in G de Búrca and J Scott (eds), The EU and the WTO: Legal and Constitutional Issues (Oxford, Hart Publishing, 2001). 
Also, the CCP is now under the general umbrella of the Union's external action, which is to be guided by the principles set out in the Treaty on European Union (TEU):

In its relations with the wider world, the Union shall uphold and promote its values and interests and contribute to the protection of its citizens. It shall contribute to peace, security, the sustainable development of the Earth, solidarity and mutual respect among peoples, free and fair trade, eradication of poverty and the protection of human rights, in particular the rights of the child, as well as to the strict observance and the development of international law, including respect for the principles of the United Nations Charter. ${ }^{20}$

Within the Treaty on the Functioning of the European Union (TFEU), the CCP is situated as the first specified area of EU external action (Part V, Title II). According to Article 206 TFEU:

By establishing a customs union in accordance with Articles 28 to 32, the Union shall contribute, in the common interest, to the harmonious development of world trade, the progressive abolition of restrictions on international trade and on foreign direct investment, and the lowering of customs and other barriers. ${ }^{21}$

Further, Article 207 TFEU expands the 'uniform principles' of the CCP to the entirety of trade in services, commercial aspects of intellectual property and foreign direct investment, and reiterates that the CCP is to 'be conducted in the context of the principles and objectives of the Union's external action. ${ }^{\text {'2 }}$ Also, the consent of the European Parliament will henceforth be required for the conclusion of trade agreements with third countries. ${ }^{23}$

The wider implications of the trade relations of the European Union have always enjoyed vivid attention from the academic community in various regards. These include such 'classics', if you will, as the relationship between the law of the World Trade Organisation (WTO) and EU law (and particularly the effect of the former in the latter order) ${ }^{24}$ the coherence debate between trade and development, human rights, environment, etc ${ }^{25}$ and, related to that, the desirability

20 Art 3(5) TEU.

21 Art 206 TFEU. Compare also the stronger language and shift in perspective ('... the Union shall contribute ...') with the weaker wording before Lisbon: 'By establishing a customs union between themselves Member States aim to contribute ...' (ex Art 131 TEC).

22 Art 207 TFEU.

23 Art 218(6)(v) juncto Art 207(2) and (3).

24 See eg P Hilpold, Die EU im GATT/WTO-System, 3rd edn (Baden-Baden, Nomos, 2009); Cebada Romero, above n 18, at 407-92; P Koutrakos, EU International Relations Law (Oxford, Hart Publishing, 2006), at 251-99; PJ Kuijper, 'From initiating proceedings to ensuring implementation: the links with the Community legal order' in G Sacerdotti, A Yanovich, J Bohanes (eds), The WTO at Ten: The Contribution of the Dispute Settlement System (Cambridge, Cambridge University Press, 2006); A von Bogdandy and T Makatsch, 'Collision, Co-existence or Co-operation? Prospects for the Relationship between WTO Law and European Union Law' in de Búrca and Scott (eds), above n 19.

25 See eg E Vranes, Trade and the Environment: Fundamental Issues in International Law, WTO Law, and Legal Theory (Oxford, Oxford University Press, 2009); N Schrijver, 'The EU's Common Development 
of conditionality, ${ }^{26}$ as well as the more recent discussion on rethinking the global order, and in particular the WTO, in 'constitutional' terms (ie the 'constitutionalisation' debate) and the EU's role therein. ${ }^{27}$

Given the extensive literature already available in all these areas, the objective of this chapter is not to revisit all these debates in detail. What it does endeavour to do is to take a step back, now that the dust of the EU's own reform processes has begun to settle after entry into force of the Lisbon Treaty, and to provide an overview of the different ways in which trade serves as a channel for interaction between the EU and the rest of the world, by way of selective, but pertinent, examples.

This will be done in the following three steps, which are not necessarily chronological but rather organised by the level of ambition the EU shows to influence the outside world. As a first step, section II. will discuss the EU's trade policy as a necessary corollary for the maintenance of its internal market. Here, European integration itself was launched in the shadow of the pre-existing General Agreement on Tariffs and Trade (GATT), and continues to be shaped within the more comprehensive WTO framework. Subsequently, section III. will address the role of trade policy as a vehicle for various other external policies of the EU. Here, the EU uses trade to export its own values and model of integration to other countries and regions. Lastly, section IV. will assess the role of the EU's trade policy in constituting and 'constitutionalising' the entire system of global economic governance.

Cooperation Policy' in M Telò (ed), The European Union and Global Governance (Abingdon, Routledge, 2009); L Bartels, 'The Trade and Development Policy of the European Union' in M Cremona (ed), Developments in EU External Relations Law (Oxford, Oxford University Press, 2008); M Carbone, The European Union and International Develoment: The Politics of Foreign Aid (London, Routledge, 2007), at 30-59; J Harrison, The Human Rights Impact of the World Trade Organisation (Oxford, Hart Publishing, 2007); H Hestermeyer, Human Rights and the WTO: The Case of Patents and Access to Medicines (Oxford, Oxford University Press, 2007); generally S Nuttall, 'Coherence and Consistency' in C Hill and M Smith (eds), International Relations and the European Union (Oxford, Oxford University Press, 2005).

26 See eg A Bigsten, 'Development policy: coordination, conditionality and coherence' in A Sapir (ed), Fragmented Power: Europe and the Global Economy (Brussels, Bruegel Books, 2007); L Bartels, Human rights conditionality in the EU's international agreements (New York, Oxford University Press, 2005).

27 See eg N Walker, 'The Politics of International Constitutions' in J Dunoff and J Trachtman (eds), Ruling the World? Constitutionalism, International Law, and Global Governance (Cambridge, Cambridge University Press, 2009); E-U Petersmann, 'Multilevel Trade Governance in the WTO Requires Multilevel Constitutionalism' in C Joerges and EU Petersmann (eds), Constitutionalism, Multilevel Trade Governance and Social Regulation (Oxford, Hart Publishing, 2006); J Trachtman, 'The Constitutions of the WTO' (2006) 17 European Journal of International Law 623; J Dunhoff, 'Constitutional Conceits: The WTO's “Constitution” and the Discipline of International Law' (2006) 17 European Journal of International Law 647; D Cass, The Constitutionalization of the World Trade Organization: Legitimacy, Democracy, and Community in the International Trading System (Oxford, Oxford University Press, 2005); N Walker, 'The EU and the WTO: Constitutionalism in a New Key' in de Búrca and Scott (eds), above n 19; R Howse and K Nicolaïdis, 'Legitimacy and Global Governance: Why Constitutionalizing the WTO is a Step Too Far' in R Porter, P Sauvé, A Subramanian and A Beviglia Zampetti (eds), Efficiency, Equity, and Legitimacy: The Multilateral Trading System at the Millenium (Washington, DC, Brookings Institution Press, 2001). 


\section{THE CCP AS A COROLLARY OF THE INTERNAL MARKET}

As a first step in appraising the interconnections between the EU and the world in terms of trade, we have to go back to the beginning of European integration itself. It started as an economic project, and retained a stark economic character, with the internal market at its core. As the Court noted in Opinion 1/75 when introducing the concept of exclusive competence in trade policy, 'a commercial policy is in fact made up by the combination and interaction of internal and external measures.'. ${ }^{28}$ Thus, as Nugent notes, without a unified CCP 'the unified internal market would not be possible. ${ }^{29}$ Consequently, the issues of the compatibility of the European project with the GATT, measures to defend the internal market and, lastly, its (partial) extension will be addressed.

\section{A. The GATT Compatibility of the Internal Market}

When the Treaty of Rome was signed in 1957, the (pre-WTO) GATT, as a protointernational organisation, had already been in place for 10 years. ${ }^{30}$ The EU did thus not found the GATT, it only succeeded, as confirmed by the ECJ in International Fruit, ${ }^{31}$ into the position of the Member States, as it had come to exercise their competence in trade through the CCP.

Therefore, the EU itself had to comply with the pre-existing international rules. The London Conference draft of 1946 already contained a provision on customs unions, which was later extended to free trade areas (FTAs) at the Havana Conference. Ultimately, this would become Article XXIV GATT, ${ }^{32}$ which constitutes an exception to the general trade rules of most-favoured nation treatment $(\mathrm{MFN})^{33}$ and non-discrimination. ${ }^{34}$ It should be recalled that earlier attempts to diverge from MFN rules and set up a structure of pan-European preferences in the period between the World Wars had failed, also due to resistance from the United States. ${ }^{35}$ According to Chase's historic account, it was therefore not with the

28 Opinion 1/75 [1975] ECR 01355, at 1363.

29 N Nugent, The Government and Politics of the European Union (Houndmills, Palgrave Macmillan, 2006), at 483.

${ }^{30}$ For an extensive historical account, see D Irwin, P Mavroidis and A Sykes, The Genesis of the GATT (Cambridge, Cambridge University Press, 2008); also I Neugärtner, 'GATT 1947' in M Hilf and S Oeter (eds), WTO-Recht: Rechtsordnung des Welthandels (Baden-Baden, Nomos, 2005).

31 Joined Cases 21 to 24-72 International Fruit [1972] ECR-01219, para 18.

32 See also Art V of the General Agreement on Trade in Services (hereafter 'GATS').

33 Art I GATT; Art II GATS.

34 Art III GATT; Art XVII GATS; See in detail G Marceau and C Reiman, 'When and How is a Regional Trade Agreement Compatible with the WTO?' (2001) 28 Legal Issues of Economic Integration 297.

35 This concerned the wheat sector. See FG von Graevenitz, 'From kaleidoscope to architecture: Interdependence and integration in wheat politics, 1927-1957' in K Patel (ed), Fertile Ground for Europe? The History of European Integration and the Common Agricultural Policy Since 1945 (BadenBaden, Nomos, 2009), at 33-36. Of course, this was in the framework of the League of Nations and in the absence of a general, multilateral MFN rule. 
Schuman Plan in mind that this exception was introduced, but due to an envisaged (but never ratified) FTA between the United States and Canada. ${ }^{36}$ This would reinforce Howse's and Nicolaïdis' claim that originally the post-war multilateral trading system was 'a product, mostly, of the Anglo-Saxon mind'. ${ }^{37}$

In any event, as de Búrca and Scott point out, 'the EEC's common market was modelled partly on the GATT, and many of the EC Treaty provisions clearly reflect this, ${ }^{38}$ making it a sort of regional mini-GATT. When European integration then reached the stage of customs union, the issue of compliance with Article XXIV GATT arose. Under this provision substantially all the trade has to be liberalised among the members of the customs union, and the level of duties with the other trading partners not part of it should on the whole not be increased. ${ }^{39}$ The most critical point in this respect concerns the EU's Common Agricultural Policy (CAP), which exempts the Union's agricultural sector from the general liberalisation of the internal market and provides it with wide-ranging protection. For Carpenter, this suffices to conclude that ' $t$ ] he Treaty of Rome clearly did not comply with the spirit of Article XXIV'. ${ }^{40}$ The CAP (especially with regard to agricultural subsidies to keep EU producers competitive) has remained a highly contentious issue to the present day, ${ }^{41}$ despite significant reform and liberalisation efforts by the EU. As Roederer-Rynning puts its, today the 'walls are still there-but they are lower'. ${ }^{42}$ However, the Article XXIV compatibility of the EU itself has never been scrutinised, neither through dispute settlement nor through the Committee on Regional Trade Agreements (CRTA). ${ }^{43}$ Given the rather soft

36 K Chase, 'Multilateralism Compromised: The Mysterious Origins of GATT Article XXIV' (2006) 5 World Trade Review 1; see also Irwin et al, above n 30, at 167-68.

37 K Nicolaïdis and R Howse, “"This is my EUtopia ...": Narrative as Power' (2002) 40 Journal of Common Market Studies 767, at 775. International trade and economic cooperation were also already part of the US-UK Atlantic Charter of 1941.

${ }^{38}$ G de Búrca and J Scott, 'The Impact of the WTO on EU Decision-making' in de Búrca and Scott (eds), above n 19, at 2; also JHH Weiler, 'The Constitution of the Common Market Place: Text and Context in the Evolution of the Free Movement of Goods' in P Craig and G de Búrca, The Evolution of EU Law (Oxford, Oxford University Press, 1999); and Eeckhout, above n 5, at 9-11.

39 Art XXIV GATT. Of course, in doing so the customs union also has to comply with the general trade rules such as MFN and national treatment. In detail see Hilpold, above n 24, at 19-85.

${ }^{40} \mathrm{~T}$ Carpenter, 'A historical perspective on regionalism' in $\mathrm{R}$ Baldwin and $\mathrm{P}$ Low (eds), Multilateralizing Regionalism: Challenges for the Global Trading System (Cambridge, Cambridge University Press, 2009), at 17.

${ }^{41}$ For an extensive account, see C Daugbjerg and A Swinbank, Ideas, Institutions, and Trade: The WTO and the Curious role of EU Farm Policy in Trade Liberalization (Oxford, Oxford University Press, 2009); and H Jessen, 'Landwirtschaft' in Hilf and Oeter (eds), above n 30.

42 C Roederer-Rynning, 'The Common Agricultural Policy: The Fortress Challenged' in H Wallace, M Pollack and A Young (eds), Policy-Making in the European Union (Oxford, Oxford University Press, 2010), at 203.

43 For the latest report of the Committee, see Report (2009) of the Committee on Regional Trade Agreements to the General Council, WT/REG/20 of 16 October 2009. It simply states that the 'factual examination' of the Treaty of Rome has been completed (at 5). See also P Mavroidis, 'Do not Ask Too Many Questions: The Institutional Arrangements for Accommodating Regional Integration within the WTO' in E Kwan Choi and JC Hartigan (eds), Handbook of International Trade (Oxford, Blackwell, 2005); and T Bender, 'GATT 1994' in Hilf and Oeter (eds), above n 30, at 180-84; on this, as well 
language of ex Article 131 TEC that the EU Member States would merely 'aim to contribute, in the common interest, to ... the progressive abolition of restrictions on international trade and the lowering of customs barriers', this can be considered as avoiding any strict commitment by the EU itself to comply with the GATT rules on customs unions. ${ }^{44}$ The stronger wording of Article 206 TFEU could thus be seen an indication of stricter adherence to GATT/WTO rules.

This does not mean, however, that the issue remains without relevance. In terms of WTO compatibility of the internal market, we also have to consider the significant enlargement of the EU from six founding members to presently 27 members. It has been widely held that enlargement has been the area in which the EU has most clearly had an impact on domestic policy abroad. Through the leverage of attraction to the prosperous internal market, it prompted candidate countries to carry out wide-ranging reforms and to absorb the entire acquis communautaire. ${ }^{45}$ By doing so, it also transcends the traditional divide between internal and external policies. This has an important trade dimension, evidenced through pre-accession agreements with the candidates with trade preferences, ${ }^{46}$ and the final integration into the EU (and its CCP) with the ensuing trade creation, as well as diversion, ${ }^{47}$ which have to conform with WTO disciplines.

\section{B. Defending the Internal Market}

Another instance where the CCP enters the picture as a necessary corollary to the internal market is where it is used to defend it from external influences considered harmful to it. This concerns first of all the classic trade defence instruments, such as antidumping and countervailing measures. ${ }^{48}$ These can be seen as the external

as on the WTO's Transparency Mechanism for Regional Trade agreements established in 2006, see Y Devuyst and A Serdarevic, 'The World Trade Organization and Regional Trade Agreements: Bridging the Constitutional Credibility Gap' (2007) 18 Duke Journal of Comparative \& International Law 1.

${ }^{44}$ M Cremona, 'Neutrality or Discrimination? The WTO, the EU and External Trade' in de Búrca and Scott (eds), above n 19, at 152.

${ }^{45}$ R Epstein and U Sedelmeier, 'Beyond Conditionality: International Institutions in Postcommunist Europe after Enlargement' in R Epstein and U Sedelmeier (eds), International Influence Beyond Conditionality: Postcommunist Europeafter EU Enlargement (London, Routledge, 2009); F Schimmelfennig, 'EU political accession conditionality after enlargement: consistency and effectiveness' (2008) 15 Journal of European Public Policy 918; generally A Tatham, Enlargement of the European Union (Alphen aan den Rijn, Kluwer, 2009).

${ }_{46} \mathrm{Eg}$ the former Europe Agreements with the Central European countries that acceded in 2004 and 2007, and the current Stabilisation and Association Agreements with the Western Balkans. As Meunier and Nicolaïdis note, 'on the eve of the [2004] enlargement, over 95\% of the trade of the EU-15 with the new entrants was already free' (Meunier and Nicolaïdis, above n 7, at 258).

47 For an account of third countries' anxiety about EU enlargement and the lack of compensatory negotiations, see Hilpold, above n 24, at 260-76; for a study on trade diversion, inter alia in the context of EU enlargement, see C Freund and J McLaren, 'On the Dynamics of Trade Diversion: Evidence from Four Trade Blocs', International Finance Working Paper No 637, June 1999.

${ }^{48}$ European Commission, Europe's trade defence instruments in a changing global economy: A Green Paper for public consultation, COM(2006) 763 final, Brussels, 6 December 2006, at 2. 
complement to the competition and State aid policy of the Union. While the latter is aimed at guaranteeing a fair and level playing field within the EU, the former combats any outside interference with, or abuse of, this playing field. ${ }^{49}$

Regarding subsidies, on the other hand, the WTO Agreement on Subsidies and Countervailing Measures defines specific categories that are either prohibited or can be challenged through dispute settlement or coutervailing measures, especially when the subsidies are used to protect one's market and adversely affect trading partners. Such a question of subsidisation concerned the disputes between the US and EU on Large Civil Aircraft, with both sides accusing the other of subsidising their respective civil aviation champions. ${ }^{50}$ Given that both Boeing and Airbus (as part of EADS) are also military producers, and that large defence equipment projects are also alleged to serve as masked subsidies, this matter is all but exclusively civil, and relates to the EU's efforts for armaments cooperation. ${ }^{51}$

More generally, this reveals that where the internal market is not fully developed, a common trade approach is also lacking. ${ }^{52}$ The absence of a truly common European defence equipment market due to an overbroad interpretation by the Member States of Article 346 TFEU $^{53}$ therefore also leads to a weaker policy in terms of arms exports, which is currently not addressed in terms of the internal market (or what used to be the first pillar) but through Common Foreign and Security Policy (CFSP) measures (the former second pillar), ${ }^{54}$ which is governed by 'specific rules and procedures' and excluded from ECJ jurisdiction. ${ }^{55}$

Also, restrictions on trade based on health concerns, which is multilaterally addressed by the Agreement on Sanitary and Phytosanitary Measures (SPS),

49 For a comprehensive account, see I van Bael and J-F Bellis, Anti-dumping and Other Trade Protection Laws of the EC, 5th edn (The Hague, Kluwer Law International, 2009); for an overview of the debate surrounding antidumping as hampering competition and developing countries' perspectives on the issue see R Raslan, Antidumping: A Developing Country Perspective (The Hague, Kluwer Law International, 2009).

50 United States-Measures Affecting Trade in Large Civil Aircraft, Request for consultations by the European Communities of 12 October 2004, WT/DS317/1; European Communities and Certain Member States-Measures Affecting Trade in Large Civil Aircraft, Request for Consultations by the United States of 12 October 2004, WT/DS316/1. These disputes are still pending due to the complexity of the issues and the volume of materials involved.

51 This matter is further complicated through transatlantic armaments co-operation, considering, eg, the controversial cancellation in late 2008 of European refuelling aircraft previously ordered by the Pentagon, and the subsequent dropping-out of Airbus from the follow-up tender.

52 M Cremona, 'The External Dimension of the Single Market: Building (on) the Foundations' in C Barnard and J Scott (eds), The Law of the Single European Market: Unpacking the Premises (Oxford, Hart Publishing, 2002).

53 Ex Art 296 TEC. Note also the close resemblance of Art 346 TFEU to Art XXI GATT.

54 Council Common Position 2008/944/CFSP of 8 December 2008 defining common rules governing control of exports of military technology and equipment [2008] OJ L335/99; Council Joint Action 2008/230/CFSP of 17 March 2008 on support for EU activities in order to promote the control of arms exports and the principles and criteria of the EU Code of Conduct on Arms Exports among third countries [2008] OJ L75/81. This also includes the cases of arms embargoes (see section III.B.). Nonetheless, the adoption of such legally binding instruments is progress in comparison to the previous regime, which existed only in the form of a code of conduct.

55 Art 24(1), 2nd indent TEU. 
demonstrate that maintaining a customs union and an internal market is not simply a matter of technical, uncontroversial 'low politics' 56 but can become a highly politicised matter. This was illustrated by the well-known cases concerning Beef Hormones ${ }^{57}$ and genetically modified organisms, GMOs. ${ }^{58}$ These raised fundamental questions about the scope of the precautionary principle in terms of health protection and the 'justiciability' of scientific evidence by the Appellate Body. ${ }^{59}$ However, the status of the EU as bulwark, or 'incidental fortress', ${ }^{60}$ against genetically modified foodstuffs has decreased following the expiry of the sixyear GMO moratorium in 2004. A recent example is the decision to allow the large-scale cultivation of the genetically modified 'Amflora' potato, ${ }^{61}$ which is only the latest addition to an already large number of GMOs permitted by the Commission. ${ }^{62}$

\section{Extending (parts of) the Internal Market}

The impact of the internal market exceeds the dimension of EU enlargement, and thus produces additional trade implications. Where accession is excluded or not politically desired (for the time being), the EU has already largely extended its internal market to the countries of the European Economic Area (EEA), Switzerland and Turkey. It also promised its post-enlargement neighbourhood a so-called 'stake in the EU's Internal Market'63 or, as former European

56 As coined by Stanley Hoffmann; S Hoffmann, The European Sisyphus: Essays on Europe, 19641994 (Boulder, Col, Westview Press, 1994).

57 European Communities-Measures Concerning Meat and Meat Products (Hormones), Appellate Body Report (adopted 13 February 1998) WT/DS26/AB/R, WT/DS48/AB/R.

58 European Communities-Measures Affecting the Approval and Marketing of Biotech Products, Panel Reports (adopted 21 November 2006) WT/DS291/R, WT/DS292/R, WT/DS293/R.

59 For discussion see W Davey, 'Reflections on the Appellate Body Decision in the Hormones Case and the Meaning of the SPS Agreement' in G Bermann and P Mavroidis (eds), Trade and Human Health and Safety (Cambridge, Cambridge University Press, 2006); A Sykes, 'Domestic Regulation, Sovereignty and Scientific Evidence Requirements', ibid.

60 A Young, 'The Incidental Fortress: The Single European Market and World Trade' (2004) 42 Journal of Common Market Studies 393.

61 Commission Decision 2010/135 of 2 March 2010 concerning the placing on the market, in accordance with Directive 2001/18/EC of the European Parliament and of the Council, of a potato product (Solanum tuberosum L. line EH92-527-1) genetically modified for enhanced content of the amylopectin component of starch [2010] OJ L53/11; Commission Decision 2010/136 of 2 March 2010 authorising the placing on the market of feed produced from the genetically modified potato EH92527-1 (BPS-25271-9) and the adventitious or technically unavoidable presence of the potato in food and other feed products under Regulation (EC) No 1829/2003 of the European Parliament and of the Council [2010] OJ L53/15.

62 In detail MA Pollack and GS Schaffer, When Cooperation Fails: The International Law and Politics of Genetically Modified Organisms (Oxford, Oxford University Press, 2009), at 245-78.

63 European Commission, European Neighbourhood Policy Strategy Paper, COM(2004) 373 final, Brussels, 12 May 2004, at 3; see also S Gstöhl, 'Blurring Economic Boundaries: Trade and Aid in the EU's Near Abroad' in D Mahncke and S Gstöhl (eds), Europe's Near Abroad: Promises and Prospects of the EU's Neighbourhood Policy (Brussels, Peter Lang, 2008); and M Cremona, 'The European 
Commission President Prodi put it, 'sharing everything with the Union but institutions' ${ }^{64}$

This has been continued in the latest recasting of the EU's relations with its close surroundings. To the East, the Joint Declaration of the Prague Eastern Partnership Summit of May 2009 called for 'New Association Agreements' to

provide for the establishment or the objective of establishing deep and comprehensive free trade areas, where the positive effects of trade and investment liberalization will be strengthened by regulatory approximation leading to convergence with EU laws and standards. ${ }^{65}$

Of special importance is also the bilateral treaty framework with Russia, in particular as long as the country remains outside of the legal framework of the WTO. Currently, this relationship is still governed by the 1997 Partnership and Cooperation Agreement (PCA) ${ }^{66}$ while negotiations for a successor agreement continue. As established at the 2005 EU-Russia Summit, this is ultimately to lead to a Common Economic Space between the two. ${ }^{67}$

Similarly, to the South, the Union for the Mediterranean, founded in July 2008 , is mandated with the establishment of an FTA by $2010 .^{68}$ Before this will be achieved, the EU has put in place a number of FTAs with individual countries. Most recently, the FTAs between the EU and Israel and the Palestinian National Authority respectively received widespread attention through the Brita case. The Court had to rule on the question whether the origin of drink-makers for sparkling water produced in the West Bank had to be considered as produce of Israel, which it declined. ${ }^{69}$ This also reveals the political sensitivities that can underlie such seemingly 'low-politics' agreements, as well as the wider announcement effect of the ECJ's rulings.

While the EU as such has been spared scrutiny by the WTO, extensions of the internal market have not. In the 1999 Turkey-Textiles case, the Appellate Body confirmed that certain quantitative restrictions on textiles could not be justified

Neighbourhood Policy: More than a Partnership?' in M Cremona (ed), Developments in EU External Relations Law (Oxford, Oxford University Press, 2008).

$64 \mathrm{R}$ Prodi, A Wider Europe-A Proximity Policy as the Key to Stability, Sixth ECSA World Conference, Speech/02/619 (2002), Brussels, 5-6 December 2002, at 6.

65 Council of the European Union, Joint Declaration of the Prague Eastern Partnership Summit, 8435/09 (Presse 78), Prague, 7 May 2009, at 7.

66 Agreement on partnership and cooperation establishing a partnership between the European Communities and their Member States, of one part, and the Russian Federation, of the other part-Protocol 1 on the establishment of a coal and steel contact group-Protocol 2 on mutual administrative assistance for the correct application of customs legislation-Final Act-Exchanges of letters-Minutes of signing [1997] OJ L327/1.

67 See in detail, C Filis and M Papadakou, 'Assessment of the common economic space' in K Nikolov (ed), Assessing the Common Spaces between the European Union and Russia (Sofia, BECSA, 2009).

68 European Commission, Barcelona Process: Union for the Mediterranean, COM(2008) 319 final, Brussels, 20 May 2008, para 10; also M Montanari, 'The Barcelona Process and the Political Economy of Euro-Mediterranean Trade Integration' (2007) 45 Journal of Common Market Studies 1011.

69 Case C-386/08 Brita GmbH v Hauptzollamt Hamburg-Hafen, judgment of 25 February 2010, nyr. 
through the customs union between the EU and Turkey. ${ }^{70}$ The Appellate Body ruled that Article XXIV GATT only serves as an exceptional defence, where

the party claiming the benefit of this defence must demonstrate that the measure at issue is introduced upon the formation of a customs union that fully meets the requirements of sub-paragraphs 8(a) and 5(a) of Article XXIV. ${ }^{71}$

and that 'that party must demonstrate that the formation of that customs union would be prevented if it were not allowed to introduce the measure at issue. ${ }^{72}$ The Appellate Body thus shows that such questions of WTO-conformity of extensions of the internal market are indeed fully justiciable, and that it is for the Appellate Body to define further the necessary benchmarks for such compatibility, ${ }^{73}$ notwithstanding any political assessment by the CRTA. ${ }^{74}$

In sum, as to the CCP as a corollary of the internal market, we can see that the Union was shaped right from the beginning, and still is being shaped, by the GATT/WTO. While the GATT/WTO conformity of the Union itself, and its enlargement, have not been scrutinised, the Appellate Body certainly exercised its review powers for non-membership extension of the internal market, as well as a number of measures pertaining to internal policies. Moreover, it becomes clear that maintaining an internal market cannot be kept separate from other policy areas. Whereas enlargement serves to as an example where the internal/external policy division is successfully transcended, other areas, such as armaments trade and agriculture, show that internal deficiencies also lead to external difficulties.

\section{THE CCP AS A VEHICLE FOR FOREIGN POLICY}

In the European Commission's 2006 Global Europe Strategy it is stated that ' $\mathrm{t}$ ] hrough our trade policies, we also seek to contribute to a range of the Union's external goals, in particular development and neighbourhood objectives. ${ }^{75}$ While the latter concerns a stake in the internal market discussed in the previous section within the framework of the EU's neighbourhood policy, let us now turn to the external aspects of trade policy proper. It is here that that the EU makes sure that its own advantages and benefits are not hampered by its trading partners. But the CCP also goes a lot further. Just as the internal market is used as the carrot in matters of enlargement and neighbourhood policy, for countries to which membership or a

\footnotetext{
70 See, for the customs union, EC-Turkey Association Council, Decision No 1/95 of 22 December 1995 on implementing the final phase of the Customs Union [1996] OJ L35/1.

71 Turkey-Restrictions on Imports of Textile and Clothing Products (Turkey-Textiles), Appellate Body Report (adopted 19 November 1999) WT/DS34/AB/R, para 58.

72 Ibid.

${ }^{73} \mathrm{Ibid}$. Note, eg, that the complete alignment of quantitative restrictions is not required to form a customs union (para 62).

74 See also Bender, above n 43, at 182-83.

75 European Commission, Global Europe: Competing in the World. A Contribution to the EU's Growth and Jobs Strategy, COM(2006) 567 final, Brussels, 4 October 2006, at 2.
} 
'stake' in the market cannot be provided, preferential treatment and market access are used as a means of conditionality to shape the domestic policies of the EU's trading partners. More recently, the EU has also put an emphasis on exporting its very model of regional integration to other parts of the world.

\section{A. Ensuring the EU's Trade Benefits Abroad}

The EU has developed specific instruments to make sure its own trade benefits are not impaired by its trading partners. Thus, while antidumping and countervailing measures prevent unfair competition distorting the internal market, EU measures are also utilised to ensure fair trading conditions abroad. The most prominent of these instruments is the Trade Barriers Regulation of 1994, ${ }^{76}$ which gives businesses and trade associations a right to lodge complaints with the European Commission where they feel they have fallen victim to non-compliance with WTO rules in third countries. This is of importance, since WTO Dispute Settlement itself is open only to WTO Member States and not to the economic operators actually concerned. Consequently, those operators have to lobby their respective governments to launch a dispute at the WTO. The Trade Barriers Regulation thus provides a formal avenue for private parties to prompt the Commission to act multilaterally. This does not extend, however, 'to a near automatic right to have one's complaint turned into a WTO dispute settlement case if it turns out to be well founded', 77 as there also needs to be a Union interest involved for the Commission to be obliged to act. ${ }^{78}$

Furthermore, the Commission is pursuing an active strategy of promoting market access and the removal of non-tariff barriers in third countries. In 2007, it integrated a reinforced Market Access Strategy into its Global Europe Strategy. ${ }^{79}$ As part of a wider dialogue between the EU, business and third countries, it has set up so-called Market Access Teams, ie networks of relevant stakeholders, which actively engage foreign authorities to remove non-tariff barriers before an actual multilateral dispute arises. ${ }^{80}$ For easy public access, it also introduced an online Market Access Database listing the trade barriers identified by the teams. ${ }^{81}$

76 Council Regulation (EC) No 3286/94 of 22 December 1994 laying down Community procedures in the field of the common commercial policy in order to ensure the exercise of the Community's rights under international trade rules, in particular those established under the auspices of the World Trade Organization [1994] OJ L349/71.

77 Kuijper, above n 24, at 273, who compares this situation with the US, where $\$ 301$ of the US Trade Act in fact grants such a right; see generally M Bronckers and N McNelis, 'The EU Trade Barriers Regulation Comes of Age' (2001) 35 Journal of World Trade 427.

78 Council Regulation (EC) No 3286/94, Arts 8(1), 11(1) and 12(1).

79 European Commission, Global Europe: A Stronger Partnership to Deliver Market Access for European Exporters (Market Access Strategy), COM(2007) 183, Brussels, 18 April 2007.

80 For an assessment of these teams, see A Tiedemann, 'EU Market Access Teams: New Instruments to Tackle Non-tariff Barriers to Trade', College of Europe EU Diplomacy Paper 9/2009, December 2009.

81 See $<$ madb.europa.eu/mkaccdb2/indexPubli.htm $>$. 


\section{B. Shaping of Foreign Governance through Trade}

The CCP, however, goes far beyond ensuring the reciprocal enjoyment of trade benefits, and has a long history of serving as a vehicle for other policy areas. With regard to developing countries it is used not only as a means of development, but also as a means of shaping governance within these countries in areas such as human rights or environmental standards. In extreme cases, the EU will even use restrictive trade measures, ie sanctions, to this end.

As stated in the 2005 European Consensus on Development, the EU is 'the most important economic and trade partner for developing countries, offering specific trading benefits to developing countries, mainly to the LDCs [least developed countries] among them. ${ }^{82}$ This development dimension of trade now also features in primary law, as the new Article 3(5) TEU mandates the EU to contribute, in its external action, to the 'free and fair trade [and the] eradication of poverty', setting out the 'context' in which also the CCP itself is to be conducted under Article 207 TFEU.

This flows from a long historical relationship between the Union's trade and development policies. As Bartels argues, development objectives were inherent in the CCP from the outset, being carried over from the ties of the Member States with their former colonies. ${ }^{83}$ This also explains the EU's categorisation of the outside (non-developed) world into African, Caribbean and Pacific (ACP) countries and everyone else. However, a special reference to the ACP-relationship in the treaties has been removed by Lisbon. ${ }^{84}$ In the GATT, a chapter on 'Trade and Development ${ }^{85}$ was added only in 1966 under the pressure of the United Nations Conference on Trade and Development (UNCTAD), which had been created as an alternative forum in the framework of calls for a new international economic order. ${ }^{86} \mathrm{~A}$ renewed emphasis on development has been put on the current round of trade negotiations, the Doha Development Round.

This special association relationship between the EU and the ACP countries was anchored in a series of international conventions, starting with Yaoundé I in 1963 and II in 1969, the four Lomé Conventions spanning the time from 1975 until 2000, and finally the Cotonou Agreement of 2000, the trade provisions of which expired in 2007. Also these agreements, by granting preferential treatment and thus derogating from WTO rules of MFN treatment and non-discrimination, raised the issue of WTO conformity.

\footnotetext{
82 Joint statement by the Council and the representatives of the governments of the Member States meeting within the Council, the European Parliament and the Commission on European Union Development Policy: The European Consensus [2006] OJ C46/1, para 2.

83 Bartels, above n 25, at 128-32.

${ }^{84}$ Ex Art 179(3) TEC. The differentiation remains, though, institutionally. While external relations are now generally handled by the European External Action Service, there remains a DirectorateGeneral for Development, which handles relations with the ACP countries.

85 Arts XXXIV to XXXVIII GATT.

${ }^{86}$ In detail see M Michaelis and H Jessen, 'WTO und Entwicklung' in Hilf and Oeter (eds), above n 30 .
} 
It is in this context that the Bananas dispute arose, which would become the EU's longest-lasting trade dispute. The United States and several Latin American countries challenged the EU's regime for the import, sale and distribution of bananas favouring ACP countries. The Appellate Body repeatedly found that the EU's preferential treatment, even after several reconfigurations, violated WTO rules. ${ }^{87}$ The EU had exceeded the derogations introduced in the GATT/WTO system favouring developing countries, as well as the special waiver granted to the EU in 1994 for the Lomé Agreement. ${ }^{88}$ Recently, the EU agreed to reduce the overall import tariffs for bananas in exchange for a no-litigation commitment from the Latin American countries. Consequently, an eroded preferential banana market organisation for the ACP countries will remain, but in order to adjust to the stiffer competition the EU decided to pay additional financial aid to the ACP countries. ${ }^{89}$ While this is arguably a positive move in terms of WTO compliance, it also appears as an implicit acknowledgement of the failure of this particular example of development through trade. More generally, the EU has abandoned its ACP-wide approach for granting trade preferences, and has moved to negotiate WTO-compatible bi-regional agreements.

Apart from this ACP-centred approach, the EU also provides for general, nonreciprocal benefits to developing countries through the WTO's 1979 'enabling clause. ${ }^{90}$ On this basis the EU, like most other developed economies, maintains a so-called Generalised System of Preferences (GSP), providing preferential access to its market for developing countries. ${ }^{91}$ The EU added to this standard GSP two other schemes: the 'Special incentive arrangement for sustainable development and good governance' (better known as GSP+), and the 'Special arrangement for the least-developed countries' (better known as 'Everything but Arms' (EBA)). In order to qualify for the additional benefits provided by GSP+, eligible developing countries, as well as being 'vulnerable economies,' ${ }^{92}$ must have 'ratified and effectively implemented all the conventions listed in Annex III', ie 27 international conventions concerning labour standards, human rights, sustainable development and good governance. ${ }^{93}$ Further, each country wishing to benefit from GSP+ has to give an undertaking that it will allow the Commission to monitor the implementation

87 European Communities - Regime for the Importation, Sale and Distribution of Bananas, Appellate Body Report (adopted 25 September 1997) WT/DS27/AB/R; see J Cascante and G Sander, Der Streit um die EG-Bananenmarktordnung (Berlin, Duncker \& Humblot, 1999).

88 GATT, The Fourth ACP-EEC Convention of Lomé, Decision of 9 December 1994, L/7604.

89 European Union, Ending the longest trade dispute in history: EU initials deal on bananas with Latin American countries, Press release P/09/1938, Brussels, 15 December 2009, available at <http://www. europa.eu/rapid/pressReleasesAction.do?reference=IP/09/1938>.

90 GATT, Decision on Differential and More Favourable Treatment, Reciprocity and Fuller Participation of Developing Countries, Decision of 28 November 1979, L/4903.

${ }^{91}$ For the current legislation in force, see Council Regulation (EC) No 732/2008 of 22 July 2008 applying a scheme of generalised tariff preferences for the period from 1 January 2009 to 31 December 2011 [2008] OJ L211/1.

92 Ibid, Art 8(1)(c) juncto Art 8(2). This comprises countries that are not high-income (as classified by the World Bank), of which exports are not diversified and of which the imports into the Union covered by the scheme amount to less than $1 \%$ in value of the total GSP-covered imports into the Union.

93 Ibid, Art 8(1)(a). 
of the conventions. ${ }^{94}$ Under EBA, least-developed countries ${ }^{95}$ are granted duty-free and quota-free access to the EU for all products, except arms and ammunitions. ${ }^{96}$ Therefore, applying for GSP+ is of little interest for the least-developed countries, while they are likely to be the ones most in need of the governance reforms that GSP+ membership would entail. The EBA arrangement therefore resembles rather a form of humanitarian assistance, which is also normally unconditional.

In terms of enforcement, the benefits under GSP+ can be withdrawn temporarily in cases where incorporation into domestic law and/or implementation of the 27 conventions on the part of the beneficiary country is lacking. ${ }^{97}$ Similarly, the benefits under all three schemes can be withdrawn temporarily, eg due to 'the serious and systematic violation' of the principles set out in the core human and labour rights conventions as established by the relevant monitoring bodies (normally the Commission)..$^{98}$ This also concerns those countries not benefitting from GSP+ and that are thus not actually obliged to ratify these conventions. Another ground for suspension comprises 'serious and systematic unfair trading practices which have an adverse effect on the [Union's] industry', which, importantly, have to be 'based on a previous determination to that effect by the competent WTO body'99 and not on an assessment by the Commission. This way, the Union ensures that these countries comply with this collection of international obligations, representing norms and values on which the EU itself is founded and promotes worldwide. ${ }^{100}$ Recently, it has withdrawn GSP+ benefits from Sri Lanka, having determined a lack of implementation of three relevant human rights conventions. ${ }^{101}$

Presently, while 176 developing countries fall under GSP and 49 under EBA, only 16 countries have qualified for GSP+. Also, the economic benefits given by the schemes may seem greater than they actually are. As Bartels points out, the GSP covers only 9 per cent of all imports into the EU, half of which is actually utilised. ${ }^{102}$ This is partly due to the complexity and restrictiveness of the rules of origin determining which products actually qualify as coming from a country covered by the scheme. ${ }^{103}$

94 Ibid, Art 8(1)(b).

95 Those are the least-developed countries according to the United Nations (ibid, Art 11(8)). Note that for the notion of 'developing country', the ECJ maintains an autonomous EU law definition, Case C-155/07, Parliament $v$ Council [2008] ECR I-08103, para 52.

96 Council Regulation (EC) No 732/2008, above n 91, Art 11. The transitional periods for bananas and rice have already expired. The one exempting sugar will expire on 30 September 2012.

97 Ibid, Art 15(2).

98 Ibid, Art 15(1)(a), referring to 'principles laid down in the conventions listed in Part A of Annex III', thus excluding Part B containing the environmental and good governance-related conventions.

99 Ibid, Art 15(1)(d).

100 See also the contributions by B de Witte, M Cremona, and G Pavlakos and J Pauwelyn in this volume.

101 Implementing Regulation (EU) No 143/2010 of the Council of 15 February 2010 temporarily withdrawing the special incentive arrangement for sustainable development and good governance provided for under Regulation (EC) No 732/2008 with respect to the Democratic Socialist Republic of Sri Lanka [2010] OJ L 45/1.

102 Bartels, above n 25, at 155-56.

103 In detail ibid, at $154-65$. 
In addition, there is a distinction between 'non-sensitive' and 'sensitive' products, the latter comprising mainly agricultural products of interest for the developing countries concerned that merely receive a reduction in tariffs (EBA apart).

The GSP scheme is not beyond judicial control by the WTO, as evidenced by the EC-Tariff Preferences dispute, in which the Appellate Body confirmed that certain forms of its conditionality were not covered by the enabling clause. ${ }^{104}$ This concerned a special 'drug regime' which granted tariff preferences as a form of assistance to the anti-drug efforts of third countries.

Next to development, the issue of environmental protection has received more heightened attention in view of the emerging threat of climate change. Both are linked through the notion of sustainable development, which features both in the EU Treaties ${ }^{105}$ and in the Preambles to the Marrakech Agreement and the Doha Ministerial Declaration. ${ }^{106}$ However, as WTO Director General Lamy pointed out,

until a truly global consensus emerges on how best to tackle the issue of climate change, WTO Members will continue to hold different views on what the multilateral trading system can and must do. ${ }^{107}$

What role WTO Dispute settlement can play here is also uncertain, but in view of the Appellate Body Report in Shrimp Turtle, ${ }^{108}$ there is a scope to consider products being made in an environmentally unfriendly way to be 'unlike' similar products using more environmentally friendly production methods. ${ }^{109}$

On the EU side, noteworthy trade-related environmental protection measures include the regulation on waste shipment, ${ }^{110}$ which transposes into EU Law the Basel Convention on the Control of Transboundary Movements of Hazardous Wastes and their Disposal, and the adherence of the Union to the Rotterdam

104 European Communities-Conditions for the Granting of Tariff Preferences to Developing Countries, Appellate Body Report (adopted 20 April 2004) WT/DS246/AB/R; see also R Howse and S Esserman, 'The Appellate Body, the WTO dispute settlement system, and the politics of multilateralism' in G Sacerdoti, A Yanovich and J Bohanes (eds), The WTO at Ten: The Contribution of the Dispute Settlement System (Cambridge, Cambridge University Press, 2006), at 69-74.

105 More prominently after Lisbon: Art 3(3) TEU on 'sustainable development of Europe'; Art 3(5) TEU on 'sustainable development of the Earth'; and Art 21(2)(d) TEU on 'sustainable economic, social and environmental development of developing countries'. See also the contribution by H Vedder in this volume.

106 WTO, Ministerial Declaration, adopted on 14 November 2001, WT/MIN(01)/DEC/1, point 6; see also points 31-33; for an extensive account, see S Maljean-Dubois, Droit de l'Organisation mondiale du commerce et protection de l'environnement (Bruxelles, Bruylant, 2003).

107 Pascal Lamy, speech to a European Parliament panel on 29 May 2008, Brussels, available at $<$ http://www.wto.org/english/news_e/sppl_e/sppl91_e.htm >.

108 United States-Import Prohibition of Certain Shrimp and Shrimp Products, Appellate Body Report (adopted 6 November 1998), WT/DS58/AB/R; see also R Howse, 'The Appellate Body Rulings in the Shrimp/Turtle Case: A New Legal Baseline for the Trade and Environment Debate' (2002) 27 Columbia Journal of Environmental Law 491.

109 For an extensive account of the 'like products' debate, see W-M Choi, 'Like products' in international trade law: towards a consistent GATT/WTO jurisprudence (Oxford, Oxford University Press, 2003).

110 Regulation (EC) No 1013/2006 of the European Parliament and of the Council of 14 June 2006 on shipments of waste [2006] OJ L190/1. 
Convention on the Prior Informed Consent Procedure for Certain Hazardous Chemicals and Pesticides in International Trade. ${ }^{111}$ These have, however, also been the site of inter-institutional turf wars between the Commission and the Council and Parliament. ${ }^{12}$ Another area where the EU has combined trade with environmental protection is through the establishment of a regional emissions trading scheme, linked on the global level to the Kyoto Protocol. ${ }^{113}$ At the WTO level, however, the Swordfish dispute shows that the EU has also not hesitated to launch a complaint against Chile for adopting conservation measures for alleged adverse effects on its trade benefits. ${ }^{114}$

Environmental conventions also figure among the conventions to be ratified in order to qualify for GSP+. ${ }^{115}$ However, while the benefits under GSP+ can be withdrawn when a country no longer effectively implements these conventions, ${ }^{116}$ the 'serious and systematic violation' of the principles of these conventions by non-GSP+ countries would not trigger suspension of GSP benefits, as they are excluded from this provision. ${ }^{117}$ These different degrees of strictness in terms of enforcement could be seen as a hint as regards a certain hierarchy between these norms in terms of importance.

Lastly, there is also the intricate relation between the CCP and the CFSP. This concerns the question of economic sanctions as the negative counterpart to trade benefits, used in order to induce compliance with international norms the Union supports. According to Article 215 TFEU, ${ }^{118}$ where a decision adopted under the 'specific rules and procedures' of the CFSP 'provides for the interruption or reduction, in part or completely, of economic and financial relations with one or more

11 Council Decision 2006/730/EC of 25 September 2006 on the conclusion, on behalf of the European Community, of the Rotterdam Convention on the Prior Informed Consent Procedure for certain hazardous chemicals and pesticides in international trade [2006] OJ L299/23.

112 While the ECJ ruled that the Rotterdam Convention fell simultaneously under the scope of the CCP and the Union's environmental policy (Case C-94/03 Commission v Council [2006] ECR I-00001), it ruled that the Waste Shipment Regulation falls outside the scope of the CCP in terms of legal basis (Case C-411/06 Commission v Parliament and Council, judgment of 8 September 2009, nyr).

113 See J Lefevere, 'Linking Emission Trading Schemes: The EU ETS and the "Linking Directive"' in D Freestone and C Streck (eds), Legal Aspects of Implementing the Kyoto Protocol Mechanisms (Oxford, Oxford University Press, 2005).

114 Chile-Measures Affecting the Transit and Importation of Swordfish, Request for consultations by the European Communities of 19 April 2000, WT/DS193/1. Chile had also brought proceedings against the EU at the International Tribunal of the Law of the Sea (ITLOS). While the ITLOS case has been discontinued, the WTO proceedings have been suspended due to a provisional arrangement between the two parties.

115 Council Regulation (EC) No 732/2008, above n 91, Annex III, Part B. These include the Montreal Protocol on Substances that Deplete the Ozone Layer, Basel Convention on the Control of Transboundary Movements of Hazardous Wastes and Their Disposal, Stockholm Convention on Persistent Organic Pollutants, Convention on International Trade in Endangered Species of Wild Fauna and Flora, Convention on Biological Diversity, Cartagena Protocol on Biosafety, Kyoto Protocol to the United Nations Framework Convention on Climate Change.

116 Council Regulation (EC) No 732/2008, above n 91, Art 15(2).

117 Ibid, Art 15(1)(a), which merely refers to 'conventions listed in Part A of Annex III', while the environmental conventions are all in Part B.

118 Ex Art 301 TEC. 
third countries', or for restrictive measures against natural or legal persons, the Council shall adopt such sanctions. Today, these usually include an arms ban and targeted ('smart') sanctions against leading persons in the third country, ${ }^{119}$ instead of overall trade restrictions with potentially damaging effects on the population. Here too, the Lisbon Treaty clarifies a previously rather ambiguous legal framework. Originally, economic sanctions were considered an act of foreign policy falling outside of the scope of Union (then Community) competence. ${ }^{120}$ In terms of effectiveness and to avoid disturbances of the internal market, they were later nonetheless 'communitarised' under the CCP, but with references to their political origin in what was known as European Political Cooperation (EPC). ${ }^{121}$ With the creation of the CFSP in Maastricht, sanctions were turned into a so-called interpillar' exercise with a dual-legal basis. ${ }^{122}$ Notwithstanding this dual character of sanctions, the ECJ had ruled that given the CCP, competence of Member States in the area of foreign policy did not exempt them from their EU law obligations, even when they exercised it in order to implement UN Security Council Resolutions. ${ }^{123}$ Instead, the Court pointed out that the application of sanctions requires uniform and effective interpretation and application by the Union as a whole. ${ }^{124}$

Common Security and Defence Policy (CSDP) missions can also be used to protect the Union's trade interests. This has been recently illustrated by the launching of the EU's first naval operation, Operation EUNAVFOR Somalia ('Atalanta'), in December 2008 to fight piracy in the Gulf of Aden, a maritime chokepoint through which a large part of trade between the EU and Asia passes. ${ }^{125}$ The mandate of this operation explicitly includes the protection of merchant vessels. ${ }^{126}$

\section{Reproducing the EU's Own Model through Trade}

While the preceding section concerned the defence of specific interests and the promotion of specific norms, it can also be observed that more recently the Union

119 Eg Council Common Position 2002/145/CFSP of 18 February 2002 concerning restrictive measures against Zimbabwe [2002] OJ L50/1.

120 Covered by ex Art 297 TEC.

121 On this development over time, see in detail P Koutrakos, Trade, Foreign Policy \& Defence in EU Constitutional Law: The Legal Regulation of Sanctions, Exports of Dual-use Goods and Armaments (Oxford, Hart Publishing, 2001), at 49-91.

$122 \mathrm{P}$ Koutrakos, 'Inter-Pillar Approaches to the European Security and Defence Policy-the Economic Aspects of Security' in V Kronenberger (ed), The European Union and the International Legal Order: Discord or Harmony? (The Hague, TMC Asser Press, 2001).

123 Case C-70/94 Fritz Werner Industrie-Ausrüstungen GmbH [1995] ECR I-03189; Case C-83/94 Criminal proceedings against Peter Leifer et al [1995] ECR I-03231; Case C-124/95 Centro-Com [1997] ECR I-00081.

124 Case C-84/95 Bosphorus [1996] ECR I-03953; Case C-177/95 Ebony Maritime [1997] ECR I-01111; for extensive accounts, see Eeckhout, above n 5, at 424-36; and Koutrakos, above n 24, at 416-52.

125 Council Joint Action 2008/851/CFSP of 10 November 2008 on a European Union military operation to contribute to the deterrence, prevention and repression of acts of piracy and armed robbery off the Somali coast [2009] OJ L301/33. See also the contribution by P Cramér in this volume.

126 Council Joint Action, above n 125, Art 2(b). 
has put a special emphasis on regional integration through trade beyond Europe. Even though the promotion of regional integration is not explicitly mentioned as one of the guiding principles of the EU's external action, it seems to be implied in the promotion of its overall interests and values. With its image of, in the words of Söderbaum, “"world champion” of regional integration' and "“natural” point of reference for regional initiatives, ${ }^{127}$ the EU aims at (partly) reproducing its own model in various other parts of the world.

Concluding FTAs serves here as a preliminary step towards such integration. Aware also of the risks of regionalism as a means of undermining the multilateral framework, the 2006 Global Europe Strategy stresses that such FTAs

if approached with care, can build on WTO and other international rules by going further and faster in promoting openness and integration, by tackling issues which are not ready for multilateral discussion and by preparing the ground for the next level of multilateral liberalisation. ${ }^{128}$

This way, it also hints at the deadlock of the Doha Round and the need for alternative, ie non-multilateral, ways to move forward. Moreover, it underlines that

Many key issues, including investment, public procurement, competition, other regulatory issues and IPR [intellectual property rights] enforcement, which remain outside the WTO at this time can be addressed through FTAs. ${ }^{129}$

Hence, FTAs are to 'serve as a stepping stone, not a stumbling block for multilateral liberalisation.' ${ }^{130}$

Taking the step from a mere FTA to regional integration is then made with a view to development. According to the 2005 European Consensus on Development, by

[d] rawing on its own experiences, and exclusive competence in trade, the Community [now Union] has a comparative advantage in providing support to partner countries to integrate trade into national development strategies and to support regional cooperation whenever possible. ${ }^{131}$

Such regional cooperation is seen in the first place as a means to reduce trade barriers between developing countries, but also to make these countries ready for cooperation with the EU. With regard to this second aspect, the internal market re-enters the picture, as the Consensus stresses that for 'many countries, but especially those for which the EU is the largest trading and investment partner, approximation of the EU single market regulations is beneficial.' ${ }^{32}$ 'Trade and

\footnotetext{
127 F Söderbaum, 'African Regionalism and EU-African Interregionalism' in M Telò (ed), European Union and New Regionalism: Regional Actors and Global Governance in a Post-Hegemonic Era, 2nd edn (Aldershot, Ashgate, 2007), at 197.

128 European Commission, above n 75, at 8.

129 Ibid.

130 Ibid.

131 The European Consensus, above n 82, para 49.

132 Ibid, para 74.
} 
Regional Integration' was also designated one of the eight strategic partnerships between the EU and Africa in 2007.133

Putting this commitment to regionalism into practice, the Union, upon expiry of the Cotonou Agreement and the waivers covering it (see section III.B.), went on to subdivide the ACP group into eight regional groups. With each of these, the EU is aiming to conclude so-called Economic Partnership Agreements (EPAs). The objective, according to the Commission, is

to establish new WTO-compatible trade arrangements ... and to support ACP regional integration and foster the smooth and gradual integration of the ACP States into the world economy, particularly by helping create larger ACP regional markets, thereby contributing to sustainable development and poverty reduction. ${ }^{134}$

In short, the EPAs are advertised as 'trade and cooperation agreements at the service of development. ${ }^{135}$ Thus far, the EU has concluded an EPA with the CARIFORUM States (but not CARIFORUM itself), ${ }^{136}$ and has put in place several other interim and so-called 'stepping-stone' agreements with individual countries while negotiations continue. However, in terms of the effectiveness of this effort to reproduce the EU's successful model elsewhere and bolster its partners' integration through trade, it is bewildering that the regional groups with which the EU is negotiating hardly match the regional arrangements already in place. ${ }^{137}$ While this may be partly due to overlaps and competing arrangements in these regions, there is a danger that by 'the splitting of existing regional arrangements into different EPA negotiating groups' the EU might actually contribute towards undermining integration processes already underway. ${ }^{138}$

Apart from this historical and development-orientated track of inter-regionalism, the EU is also engaged in inter-regional cooperation with other parts of the world, usually with the goal of creating comprehensive inter-regional FTAs. ${ }^{139}$ Of particular importance here is the envisaged EU-MERCOSUR FTA, which has been

133 Council of the European Union, The Africa-EU Strategic Partnership: A Joint Africa-EU Strategy, Lisbon, 9 December 2007, 16344/07 (Presse 291), at 10-12.

134 European Commission, Economic Partnership Agreements, COM(2007) 635 final, Brussels, 23 October 2007, at 2.

135 Report from the Commission to the Council and the European Parliament, Annual Report 2009 on the European Community's Development and External Assistance Policies and their Implementation in 2008, SEC(2009) 831 final, Brussels, 30 June 2009, at 16.

${ }^{136}$ Economic Partnership Agreement between the CARIFORUM States, of the one part, and the European Community and its Member States, of the other part [2008] OJ L289/3. CARIFORUM is an umbrella organisation comprising the Caribbean Community (CARICOM, a single market with 15 Member States) and the Dominican Republic.

137 In detail Bartels, above n 25, at 166-69.

$138 \mathrm{Ibid}$, at 167; see also Söderbaum, above n 127, at 199, stressing the asymmetric nature of these relationships (in Africa) and calling the EU's approach even 'soft imperialism'; also critical are P Draper and M Qobo, 'Multilateralizing regionalism: case study of African regionalism' in R Baldwin and P Low (eds), Multilateralizing Regionalism: Challenges for the Global Trading System (Cambridge, Cambridge University Press, 2009).

139 See F Söderbaum and L van Langenhove, 'Introduction: The EU as a Global Actor and the Role of Interregionalism' (2009) 27 Journal of European Integration 249; and N Alecu de Flers and 
negotiated for a decade now, and which would, when concluded, constitute the first inter-regional FTA (ie MERCOSUR itself would be a member). ${ }^{140}$ Another example is an envisaged FTA between the EU and ASEAN that the Commission has been negotiating since April 2007. ${ }^{141}$ With negotiations paused, however, the Union has begun to negotiate bilateral agreements with individual countries, which, according to Trade Commissioner De Gucht, are to serve as 'an important stepping-stone in the EU's engagement with the ASEAN region.. ${ }^{142}$

This adherence to regional integration does not, however, stop the Union from 'cracking open' other trade arrangements in a dispute settlement procedure where its own commercial interests are impaired, as can be seen in the Brazilian Tyres dispute. There, the EU succeeded with a WTO complaint against Brazil for imposing an import ban on retreaded tyres, inter alia based on health grounds. Given that the import ban did not apply to Brazil's fellow MERCOSUR members following a MERSOCUR dispute settlement procedure, the Appellate Body ruled that this constituted discriminatory treatment vis-à-vis non-MERCOSUR countries. ${ }^{143}$ This can be contrasted with attempts by other WTO members to attack individual EU Member States, eg in the Asbestos dispute, which failed as it was always the Union as a whole that responded to complaints. ${ }^{144}$

In sum, regarding the CCP as a vehicle for foreign policy, it might be observed that the Union interacts in various ways through trade with the other parts of the world. In addition to merely ensuring compliance in respect of its own trade benefits, it has also created elaborate schemes and arrangements, and linked different policy areas, in order to promote its interests and values. However, the interest of

E Regelsberger, 'The EU and Inter-regional Cooperation' in C Hill and M Smith (eds), International Relations and the European Union (Oxford, Oxford University Press, 2005).

140 MERCOSUR (Mercado Común del Sur) is a regional trade agreement with four Latin American member countries. The arrangement already in place is the Interregional Framework Cooperation Agreement between the European Community and its Member States, of the one part, and the Southern Common Market and its Party States, of the other part [1996] OJ L69/4. See also A Vasconcelos, 'European Union and MERCOSUR' in Telò (ed), above n 127. Negotiations on a trade agreement with the Andean countries, on the other hand, have thus far not envisaged the Andean Community of Nations as a party.

${ }^{141}$ In detail see A Petchsiri, 'ASEAN to AFTA: from peace and security zone to free trade area and beyond?' in A Ott and E Vos (eds), Fifty Years of European Integration: Foundations and Perspectives (The Hague, TMC Asser Press, 2009).

142 European Commission, DG Trade, EU to start bilateral trade negotiations with Singapore, press release, available at $<$ http://www.trade.ec.europa.eu/doclib/press/index.cfm?id=519\&serie=320\&langI $\mathrm{d}=\mathrm{en}>$. A similar FTA is also being negotiated with the Gulf Cooperation Council countries.

143 Brazil-Measures Affecting Imports of Retreaded Tyres, Appellate Body Report (adopted 17 December 2007) WT/DS332/AB/R, paras 226-39. Note also that on appeal '[ $t$ ] he European Communities [now EU] further criticize[d] the Panel for not verifying whether MERCOSUR is a customs union that complies with the requirements of Article XXIV of the GATT 1994' (para 32).

144 EC-Measures Affecting Asbestos and Asbestos-Containing Products, Appellate Body Report (adopted 5 April 2001) WT/DS135/AB/R. See also J Heliskoski, Mixed Agreements as a Technique for Organizing the International Relations of the European Community and Its Member States (The Hague, Kluwer Law International, 2001), at 178-93. Of course, MERCOSUR itself is not a WTO member against which a complaint could be launched. 
the addressees in being thus shaped turns out to be rather limited, and is met with hostility by others who feel discriminated against. What is remarkable about the renewed emphasis on regionalism is the shift from advertising (inter-) regional FTAs as stepping-stones to truly multilateral free and fair trade, to promoting bilateral FTAs (ie EU with a single third country) as stepping-stones to regional or inter-regional FTAs (ie EU with several third countries from another region, or even another regional organisation). Consequently, while awaiting such true inter-regionalism (and further down the road, true multilateralism), the EU is engaged in rather asymmetrical relationships by negotiating with individual third countries. Later, after the conclusion of such bilateral FTAs, the added value to the $\mathrm{EU}$ in pursuing further the conclusion of regional FTAs is questionable, especially in terms of conditionality leverage. Moreover, offering FTAs to a wider range of countries also puts in question the 'special' nature of the relationship of the Union with its neighbourhood, since ultimately a 'stake in the internal market', in terms of deep integration going beyond trade in goods, can be offered regardless of geographic location.

\section{THE CCP AS CONTRIBUTOR TO CONSTITUTIONALISATION}

Having discussed the ways in which trade influences the EU's own order, as well as the ways in which the EU influences other countries and regions through trade, we now turn to the relationship between the EU and the system as a whole. This concerns primarily the relationship between the EU and the WTO as the global institutional framework for trade. We shall look in turn at the role of the EU within the WTO, at the present relationship between these two legal orders and at how this relationship relates to the debate on the 'constitutionalisation' of the international system.

\section{A. The EU and the Uruguay Round}

Whereas, as we saw above, European economic integration itself can be seen 'as a child of the GATT', ${ }^{145}$ the EU, alongside its Member States, served as one of the founding fathers of the WTO, providing considerable input for its establishment in 1995 at the conclusion of the Uruguay Round. ${ }^{146}$ The EU's status as

145 Cremona, above n 44, at 151-52.

146 This despite various internal competence disputes and institutional turf wars: see P van den Bossche, 'The European Community and the Uruguay Round Agreements' in J Jackson and A Sykes (eds), Implementing the Uruguay-Round (Oxford, Clarendon Press, 1997); F Behrens, 'Uruguay-Runde und Gründung der WTO' in Hilf and Oeter (eds), above n 30; and M Beise, Die Welthandelsorganisation (WTO): Funktion, Status, Organisation (Baden-Baden, Nomos 2001), at 73-75. 
an original member of the WTO is recognised in the Marrakech Agreement. ${ }^{147}$ In terms of decision-making, it is specifically acknowledged that whenever 'the European Communities exercise their right to vote, they shall have a number of votes equal to the number of their member States.' ${ }^{148}$ This is remarkable, given that the $\mathrm{EU}$ often experiences problems in joining international organisations and UN agencies due to their 'States only' membership, and thus is often allowed to participate only as an observer. ${ }^{149}$ This is both a reflection of the existing GATT practice of the EU succeeding into the Member States' exercise of competence, as well as of the more flexible membership of the WTO which is open to any 'State or separate customs territory possessing full autonomy in the conduct of its external commercial relations. ${ }^{150}$ This also allows non-countries, such as Hong Kong and Macao, to be members. However, the EU did not embrace its new creation too closely, as the Council Decision for the conclusion of the Uruguay Round Agreements already stipulated in the Preamble that 'by its nature, the Agreement establishing the World Trade Organization, including the Annexes thereto, is not susceptible to being directly invoked in Community or Member State courts. ${ }^{151}$ The issue of (lack of) direct effect of WTO law would become a defining feature of the relationship between these two legal orders (see section IV.B.).

Given the changes introduced by the Lisbon Treaty, above all the absorption of the Community by the Union and the now exclusive Union competence for the entire CCP, not only the name had to be changed to 'European Union' as a WTO member, but also the parallel membership of the Member States appears increasingly superfluous given their lack of competence. ${ }^{152}$ Thus far the EU remains the only supranational member and actor within the WTO.

As far as the setting-up of the WTO itself is concerned, it may be described as a watershed in the sophistication of international governance. First, the scope of international trade issues under its institutionalised umbrella expanded from

\footnotetext{
147 Marrakech Agreement Establishing the WTO, Art XI(1), listing as the 'Original Membership' the 'contracting parties to GATT 1947 ... and the European Communities'.

$148 \mathrm{Ibid}, \operatorname{Art} \mathrm{IX}(1)$.

149 F Hoffmeister and PJ Kuijper, 'The Status of the European Union at the United Nations: Institutional Ambiguities and Political Realities' in J Wouters, F Hoffmeister and T Ruys (eds), The United Nations and the European Union: An Ever Stronger Partnership (The Hague, TMC Asser Press, 2006), 9-34; I Govaere, J Capiau and A Vermeersch, 'In-Between Seats: the Participation of the European Union in International Organizations' (2004) 9 European Foreign Affairs Review 155; also Eeckhout, above n 5, at 199-206.

150 Marrakech Agreement Establishing the WTO, Art XII(1).

151 Council Decision 94/800/EC of 22 December 1994 concerning the conclusion on behalf of the European Community, as regards matters within its competence, of the agreements reached in the Uruguay Round multilateral negotiations (1986-1994) [1994] OJ L336/1.

152 The WTO Agreements have now become what Schermers dubbed 'false' mixed agreements; see HG Schermers, 'A Typology of Mixed Agreements' in D O'Keeffe and HG Schermers (eds), Mixed Agreements (Deventer, Kluwer Law and Taxation, 1983), at 27.
} 
goods to services (GATS) ${ }^{153}$ and intellectual property rights (TRIPS). ${ }^{154}$ Secondly, the institutional structure was changed from an almost entirely member-driven negotiating forum to a more rule-based system. A Trade Policy Review Mechanism was established, periodically monitoring the WTO members' performance. ${ }^{155}$

Arguably the most important institutional change was the judicialisation of dispute settlement. According to former WTO Director General Ruggerio, this represents 'the heart of the WTO system. ${ }^{156}$ Under the old GATT, panel reports could easily be turned down because of the consensus required among the Contracting Parties for their adoption, and the enforcement mechanism was only rudimentary. Under the new Understanding on Rules and Procedures Governing the Settlement of Disputes (DSU), ${ }^{157}$ on the contrary, reports by panels and the newly-established permanent Appellate Body are adopted within a strict timeframe and on the basis of so-called 'reverse consensus', ie unless there is consensus among the members gathered as the Dispute Settlement Body (DSB) not to adopt the reports, they shall be adopted. ${ }^{158}$ In case of non-compliance with WTO obligations, the member whose measures have been deemed WTOinconsistent can be ordered to pay compensation by the DSB, or the DSB can authorise suspension of concessions by the complaining member, which can also be cross-sector. ${ }^{159}$

This distinguishes the WTO dispute settlement mechanism from the procedures before the International Court of Justice, which requires the consent of all the parties to a dispute in order to have jurisdiction and which cannot rely on an organised enforcement mechanism. ${ }^{160}$ But given that only WTO members, and not individuals, have access to WTO dispute settlement, its jurisdiction is more

\footnotetext{
153 See eg P Eeckhout, 'Constitutional Concepts for Free Trade in Services' in de Búrca and Scott (eds), above n 19.

154 For an extensive account of this agreement and its role in the EU legal order, see C Hermes, TRIPS im Gemeinschaftsrecht: Zu den innergemeinschaftlichen Wirkungen von WTO-Übereinkünften (Berlin, Duncker \& Humblot, 2002). The WTO also covers several other multilateral and so-called plurilateral agreements (ie not binding all WTO members).

155 Annex 3 to the Marrakech Agreement Establishing the WTO; see also M Gehring, 'Mechanismus zur Überprüfung der Handelspolitik (TPRM)' in Hilf and Oeter (eds), above n 30.

156 Cited in M Hilf, 'Das Streitbeilegunssystem der WTO' in Hilf and Oeter (eds), above n 30, at 506; see also eg T Cottier, 'Dispute Settlement in the World Trade Organization: Characteristics and Structural Implications for the European Union' (1998) 35 CML Rev 325; J Jackson, 'The WTO dispute settlement system after ten years: the first decade's promises and challenges' in Y Tanigushi, A Yanovich and J Bohanes (eds), The WTO in the Twenty-first Century: Dispute Settlement Negotiations, and Regionalism in Asia (Cambridge, Cambridge University Press, 2007); and EU Petersmann, 'WTO dispute settlement practice 1995-2005: Lessons from the past and future challenges' in Tanigushi et al (eds), ibid.

157 Annex 2 to the Marrakech Agreement Establishing the WTO.

158 Arts 16(4) and 17(4) DSU; see P van den Bossche, 'From afterthought to centrepiece: the WTO Appellate Body and its rise to prominence in the world trading system' in G Sacerdotti, A Yanovich, J Bohanes (eds), The WTO at Ten: The Contribution of the Dispute Settlement System (Cambridge, Cambridge University Press, 2006).

159 Art 22 DSU.

160 Statute of the International Court of Justice, Art 36, and UN Charter, Art 94.
} 
limited than that of of the ECJ ${ }^{161}$ or the European Court of Human Rights. ${ }^{162}$ Private parties are allowed to submit amicus curiae briefs only in certain circumstances, as the Appellate Body decided in Asbestos. ${ }^{163}$ This was widely seen by the WTO members as an act exceeding the Appellate Body's competence, and initially did not receive support from the EU. ${ }^{164}$

Thus far, the EU itself has made ample use of the WTO's dispute settlement mechanism. It has acted as complainant in 81 cases and was respondent in 67 cases, making it the second most active member after the US with 94 cases as complainant, and 109 as respondent. The EU and US have faced each other in 50 disputes. ${ }^{165}$ Even though the EU has suffered suspension of concessions itself (for instance in the course of the Bananas disputes, see section III.B.), it has also achieved some remarkable successes through dispute settlement. One prominent example would be the withdrawal of steel tariffs by the US in late 2003. ${ }^{166}$

\section{B. WTO Law Obligations and the Union Legal Order}

With the EU having contributed to the establishment of the WTO, with as its hallmark the judicialisation of the system, we now turn to the effects of this on the Union legal order. Generally, just as under Nice, also under Lisbon, '[a]greements concluded by the Union are binding upon the institutions of the Union and on its Member States. ${ }^{167}$ As to their place in the hierarchy of norms, the ECJ established that international agreements are superior to national law and secondary Union law. ${ }^{168}$ The agreements in the WTO framework are no exception in these respects.

However, the ECJ has always accorded a special place to the WTO agreements in terms of enforceability. For the pre-WTO GATT, the Court pointed to its

\footnotetext{
161 Art 263(4) TFEU (ex Art 230 TEC).

162 European Convention on Human Rights, Art 34. This would of course presuppose that WTO law is intended to confer individual rights, which is a contentious issue related to the wider question of 'constitutionalisation' (see section IV.C.).

163 European Communities-Measures Affecting Asbestos and Asbestos-Containing Products, Communication from the Appellate Body of 8 November 2000, WT/DS135/9.

164 Nicolaïdis and Howse, above n 37, at 786; and J Wouters and B De Meester, The World Trade Organization: A Legal and Institutional Analysis (Antwerp, Intersentia, 2007), at 251-53.

${ }_{165}$ WTO, Disputes by country, available at $<$ http://www.wto.org/english/tratop_e/dispu_e/dispu_ by_country_e.htm>. On transatlantic trade disputes in detail, see E-U Petersmann, 'Prevention and Settlement of Transatlantic Economic Disputes: Legal Strategies for EU/US Leadership' in EU Petersmann and MA Pollack (eds), Transatlantic Economic Disputes: The EU, the US and the WTO (Oxford, Oxford University Press, 2003).

166 United States-Definitive Safeguard Measures on Imports of Certain Steel Products (EC), Appellate Body Report (adopted 10 December 2003) WT/DS248/AB/R.

167 Art 216(2) TFEU (ex Art 300(7) TEC).

168 Case C-61/94 Commission v Germany [1996] ECR I-03989.
} 
settled law that GATT, which according to its preamble is based on the principle of negotiations undertaken on the basis of 'reciprocal and mutually advantageous arrangements', is characterised by the great flexibility of its provisions, in particular those conferring the possibility of derogation, the measures to be taken when confronted with exceptional difficulties and the settlement of conflicts between the contracting parties. ${ }^{169}$

This in turn prevented both individuals and Member States from relying on GATT in order to have acts of the Union reviewed, ${ }^{170}$ or directly applying GATT rules in the domestic legal systems of the Member States. ${ }^{171}$ The Court carved out two exceptions to this rule: first, as established in Fediol, for legislation through which the Union intended to implement a particular obligation under GATT; ${ }^{172}$ and, secondly, as established in Nakajima, where Union legislation specifically refers to GATT provisions (so far only the case for anti-dumping). ${ }^{173}$

The advent of the WTO did not substantially change that position for the Court. Even though it acknowledged that the new

WTO agreements ... differ significantly from the provisions of GATT 1947, in particular by reason of the strengthening of the system of safeguards and the mechanism for resolving disputes, the system resulting from those agreements nevertheless accords considerable importance to negotiation between the parties. ${ }^{174}$

Hence, given that the DSU provided for interim alternative measures to immediate compliance in the form of compensation payments, ${ }^{175}$ the Court reasoned that granting direct effect to WTO law would limit the Union's negotiating capacity. ${ }^{176}$ The Court referred, in addition, to a lack of reciprocity should direct effect be accorded, given that other WTO members, including the EU's 'most important commercial partners', did not make WTO rules directly applicable in their domestic legal systems either. ${ }^{177}$

169 Case C-280/93 Germany v Council [1994] ECR I-04973, para 106; Joined Cases 21 to 24-72 International Fruit [1972] ECR-01219; see also M Bronckers and PJ Kuijper, 'WTO Law in the European Court of Justice' (2005) 42 CML Rev 1313.

170 Case C-280/93 Germany v Council [1994] ECR I-04973, para 109.

171 Ibid, para 110; also Case C-377/02 Van Parys v Belgisch Interventie- en Restitutiebureau [2005] ECR I-01465.

172 Case 70/87 Fediol v Commission [1989] ECR 1781. This case concerned the predecessor to the current Trade Barriers Regulation.

173 Case C-69/89 Nakajima v Council [1991] ECR I-2069. These appear to be the only two exceptions recognised by the Court, see Case C-377/02 Van Parys v Belgisch Interventie- en Restitutiebureau [2005] ECR I-01465, paras 39-40.

174 Case 149/96 Portugal v Council [1999] ECR I-8395, para 36.

175 Art 22(1) DSU. Note also that the 'preferred' mode of settlement of the DSU is the parties reaching a mutually agreed solution, 'consistent with the covered agreements' (Art 3(7) DSU).

176 Case 149/96 Portugal $v$ Council [1999] ECR I-8395, paras 37-42.

177 Ibid, para 43. 
This reasoning has attracted severe criticism as being politically motivated. ${ }^{178}$ As Advocate General Colomer put it in his Opinion in the Merck case, 'the Court of Justice has transformed the implementation in the Community of the ius gentium, and of the WTO agreements, into a means of evading its obligations.'179 His reference also to international law more generally is quite appropriate, given that in a string of recent judgments, it appears that the former exception of the non-enforceability of WTO agreements is becoming the rule for international law in general, extending, for instance, to the United Nations Convention on the Law of the Sea (Intertanko) ${ }^{180}$ as well as, albeit under somewhat different circumstances, the United Nations Charter (Kadi and Al Barakaat). ${ }^{181}$ Moreover, in the FIAMM \& Fedon case, the Court denied non-contractual liability of the Union in cases where individuals had suffered damages from suspensions of concessions authorised by the DSB following non-compliance with WTO obligations by the Union. ${ }^{182}$

However, short of granting direct effect, the ECJ has developed the concept of harmonious interpretation with WTO law. In Schieving Nijstad ${ }^{183}$ and Dior, ${ }^{184}$ the Court gave detailed guidance to national courts on how to conduct national procedures in conformity with the TRIPS agreement. ${ }^{185}$ Also, according to Bronckers, the Court may be tacitly pushing for compliance with WTO obligations through what he calls a 'muted dialogue' between the Court and the Appellate Body. ${ }^{186} \mathrm{He}$

178 See eg E-U Petersmann, 'Darf die EG das Völkerrecht ignorieren?' (1997) 8 Europäische Zeitschrift für Wirtschaftsrecht 325; see generally on this extensively covered area P Craig and G de Búrca, EU Law: Text, Cases and Materials, 4th edn (Oxford, Oxford University Press, 2008), at 206-13; Cebada Romero, above n 18, at 436-90; and M Herdegen, Europarecht, 6th edn (Munich, CH Beck, 2004), at 389-96.

179 Case C-431/05 Merck, Opinion of AG Ruiz-Jarabo Colomer, delivered on 23 January 2007, [2007] ECR I-07001, para 78; referring to P Pescatore, 'Free World Trade and the European Union' in A Pérez van Kappel and W Heusel (eds), Free World Trade and the European Union-The reconciliation of Interest and the Review of the Understanding on Dispute Settlement in the Framework of the World Trade Organisation (Cologne, Bundesanzeiger, 2000), at 12.

180 Case C-308/06 Intertanko [2008] ECR I-04057.

181 Joined Cases C-402/05 P and C-415/05 P Kadi and Al Barakaat [2008] ECR I-06351. Of course, the EU is not a member of the UN, and the ECJ did indeed stress the special importance of the UN Charter (paras 293-98) and showed awareness of the specificities of the UN sanctions regime in its decision (paras 361-65); for discussion, see G de Búrca, 'The European Courts and the Security Council: Between Dédoublement Fonctionnel and Balancing of Values: Three Replies to Pasquale De Sena and Maria Chiara Vitucci' (2009) 20 European Journal of International Law 853; and G de Búrca, 'The ECJ and the International Legal Order after Kadi' (2010) 51 Harvard International Law Journal 1. See also the contribution by Tridimas in this volume.

182 Joined Cases C-120/06 P and C-121/06 P FIAMM \& Fedon [2008] ECR I-06513. The noncompliance concerned, once again, the EU-ACP preferential scheme on bananas.

183 Case C-89/99 Schieving Nijstad [2001] ECR I-5851.

184 Joined Cases C-300/98 and C-392/98 Parfums Christian Dior [2000] ECR I-11307.

185 See also Kuijper, above n 24, at 270-71.

186 M Bronckers, 'From "Direct Effect" to "Muted Dialogue"' (2008) 11 Journal of International Economic Law 885. 
observes that the ECJ in the Ikea ${ }^{187}$ and FTS International ${ }^{188}$ cases found measures to be inconsistent with Union law due to use of the zeroing methodology in calculating dumping margins, but without referring to prior findings of the WTO Appellate Body establishing a similar inconsistency in terms of WTO law. Taking into account that in Kadi and Al-Barakaat too, the Court managed to avoid (for the time being) putting both the EU and the Member States in a state of noncompliance with UN Security Council resolutions by temporarily extending the application of the annulled measures, ${ }^{189}$ this can be seen as part of a more general pattern. These rather subtle ways of compliance with international obligations might ultimately refute Colomer's claim that the Court is actively trying to evade the EU's international obligations or, as de Búrca argues, 'has adopted a largely instrumentalist and self-serving approach'190 not so 'different from the US in its hard-headed, pick-and-choose attitude to international obligations.' ${ }^{191}$ Picking up on the zeroing example, compliance by the US is still wanting, despite numerous Appellate Body rulings and compliance proceedings. ${ }^{192}$

\section{The EU, the WTO and the Multiplicity of 'Constitutional' Claims}

Having looked at how the EU constituted the WTO, and how the two legal orders relate to each other, we can now turn to the question of the actual 'constitutionalisation' of the WTO and the role of the EU therein. This has been a hotly debated topic during recent years, but for both those opposed and those in favour, the EU has served as a point of reference or benchmark in discussing the degree

187 Case C-351/04 Ikea v Commissioners of Customs \& Excise [2007] ECR I-7723; the corresponding Appellate Body report is European Communities-Anti-Dumping Duties on Imports of Cotton-Type Bed Linen from India, Appellate Body Report (adopted 12 March 2001) WT/DS141/AB/R.

188 Case C-310/06 FTS International v Belastingdienst-Douane West [2007] ECR I-6749; the corresponding Appellate Body report is European Communities-Customs Classification of Frozen Boneless Chicken Cuts, Appellate Body Report (adopted 27 September 2005) WT/DS269/AB/R, WT/DS286/ $\mathrm{AB} / \mathrm{R}$.

${ }^{189}$ Joined Cases C-402/05 P and C-415/05 P Kadi and Al Barakaat [2008] ECR I-06351, paras 373-76; see J Larik, 'Two Ships in the Night or in the Same Boat Together: Why the European Court of Justice Made the Right Choice in the Kadi Case', College of Europe EU Diplomacy Paper 3/2009, June 2009, at 18-20.

190 de Búrca, 'The European Courts and the Security Council', above n 181, at 853.

$191 \mathrm{Ibid}$, at 854; generally on the EU's compliance with WTO law, see A Tancredi, 'EC Practice in the WTO: How Wide is the "Scope for Manoeuvre"?' (2004) 15 European Journal of International Law 933.

192 Eg United States-Measures Relating to Zeroing and Sunset Reviews, Appellate Body Report (adopted 23 January 2007) WT/DS322/AB/R; United States_Laws, Regulations and Methodology for Calculating Dumping Margins (zeroing), Appellate Body Report (adopted 9 May 2006) WT/DS294/AB/ R; see for the relevant US case at the United States Court of Appeal for the Federal Circuit, Corus Staal BV v Dep't of Commerce, 395 F.3d 1343 (Fed Cir 2005); for discussion see J Greenwald, 'After Corus Staal-Is There Any Role, and Should There Be-For WTO Jurisprudence in the Review of US Trade Measures by US Courts?' (2007) 39 Georgetown Journal of International Law 199. In late January 2010, the EU requested the DSB to authorise suspension of concessions. 
of the WTO's 'constitutionalisation' or its desirability. ${ }^{193}$ Instead of reopening this debate, this section aims at putting the EU-WTO dichotomy in the wider context of multiple 'constitutional' claims in today's multilevel and multisector governance.

As appropriately summarised by Oeter, the 'constitutionalisation' of international law means the transformation of that legal order into a 'Wertordnung' (normative order) based on common principles and a shared understanding of public goods ultimately detached from the ad hoc consensus of States. ${ }^{194}$ In the WTO context, the process towards 'constitutionalisation' would then be captured by the shift from a 'member-driven' to a 'rule-based system'. Such a detachment from (short-term) State interests is primarily carried by the WTO's dispute settlement mechanism and its quasi-compulsory jurisdiction, while democratic legitimacy as well as regulatory powers are deficient due to the continuing paramount importance of the States' executive branches as trade negotiators, ${ }^{195}$ ie the organisation has remained 'member-driven' to a large extent. As only States can be the parties in WTO dispute settlement procedures, so the effectiveness of its capacity to protect individual rights (at least for those considering such rights part of the Wertordnung $)^{196}$ is also limited.

Notwithstanding individual rights and democratic legitimacy, it is also important to consider the expansion of the WTO's agenda to development and the environment. Such an expanded agenda is indeed called for, given that otherwise the 'constitutionalisation' of WTO law would go hand in hand with the 'fragmentation' of international law. ${ }^{197}$ This is to recall that just as trade policy is linked in its operation to various other policy areas, different legal orders (or sub-orders) are also linked. Hence, we are today faced with several competing 'constitutional' claims from entities beyond the State. This refers, next to the EU of course, also to the United Nations and the European Convention on Human Rights (ECHR). Without being ignorant of one another, but also not showing unlimited

193 See Nicolaïdis and Howse, above n 37; and references under n 27.

194 S Oeter, 'Welthandelsordnung im Spannungsfeld von Wirtschaft, Recht und Politik' in Hilf and Oeter (eds), above n 30, at 17-18; for an in-depth discussion of the concepts of 'constitution' and 'constitutionalism', see A Stone Sweet, 'Constitutionalism, Legal Pluralism, and International Regimes' (2009) 16 Indiana Journal of Global Legal Studies 621, at 623-31.

195 Oeter, above n 194, at 16-19.

196 E-U Petersmann, 'Time for a United Nations "Global Compact” for Integrating Human Rights into the Law of Worldwide Organizations: Lessons from European Integration' (2002) 13 European Journal of International Law 621; S Peers, 'Fundamental Rights or Political Whim? WTO Law and the European Court of Justice' in de Búrca and Scott (eds), above n 19; for a critique, see P Alston, 'Resisting the Merger and Acquisition of Human Rights by Trade Law: A Reply to Petersmann' (2002) 13 European Journal of International Law 815; for an overview, see S Hörmann, 'WTO und Menschenrechte' in Hilf and Oeter (eds), above n 30.

197 See Fragmentation of International Law: Difficulties Arising From the Diversification and Expansion of International Law, Report of the Study Group of the International Law Commission Finalized by Martti Koskenniemi, A/CN.4/L.682, 13 April 2006. In the report, the EU, the WTO and human rights regimes had received particular attention as possible 'self-contained regimes'. 
deference, a complicated interplay between these orders, as well as with the established national constitutional orders, unfolds.

For the UN, despite the wealth of academic literature proclaiming the UN Charter as a world constitution, ${ }^{198}$ it is evident that unlike the three other cases there is no compulsory judicial review, not even for States or for the UN's own institutions. ${ }^{199}$ In relation to the WTO, a clear rule of conflict is set out in Article XXI(c) GATT on 'security exceptions', allowing a WTO member 'any action in pursuance of its obligations under the United Nations Charter for the maintenance of international peace and security'. This indicates that WTO law obligations (and arguably any implied human rights obligations in WTO law) could not be used as justification for failure to comply with UN Charter obligations.

For the EU, things are quite different, setting it far apart from the WTO. First, the 'constitutional' character of the Union legal order is not just something discussed academically, even though there it has been with great rigour. ${ }^{200}$ The 'constitutional' quality of EU primary law and its general principles (including fundamental rights) has been proclaimed by the ECJ itself, in a process starting from recognising the EU as 'a new legal order of international law', ${ }^{201}$ to a 'community based on the rule of law' with the Treaties as its 'constitutional charter. ${ }^{202}$ Given the hierarchy within EU law (see section IV.B.), the Court made it clear in Kadi and Al-Barakaat that

the obligations imposed by an international agreement cannot have the effect of prejudicing the constitutional principles of the EC Treaty, which include the principle that all Community acts must respect fundamental rights, that respect constituting a condition of their lawfulness which it is for the Court to review in the framework of the complete system of legal remedies established by the Treaty. ${ }^{203}$

198 See eg B Fassbender, 'Rediscovering a Forgotten Constitution: Notes on the Place of the UN Charter in the International Legal Order' in J Dunhoff and J Trachtman (eds), Ruling the World? Constitutionalism, International Law, and Global Governance (Cambridge, Cambridge University Press, 2009); S Kadelbach and T Kleinlein, 'Überstaatliches Verfassungsrecht: Zur Konstiutionalisierung im Völkerrecht' (2006) 44 Archiv des Völkerrechts 236; T Franck, 'Is the UN Charter a Constitution?' in Jochen Frowein et al (eds), Verhandeln für den Frieden/Negotiating for Peace: Liber Amicorum Tono Eitel (Berlin, Springer, 2003); and P-M Dupuy, 'The Constitutional Dimension of the Charter of the United Nations Revisited' (1997) 1 Max Planck Yearbook of United Nations Law 1.

199 For the relevant ICJ case, see Questions of Interpretation and Application of the 1971 Montreal Convention arising from the Aerial Incident at Lockerbie (Libyan Arab Jamahiriya $v$ United States of America), Request for the indication of Provisional Measures, Order of 14 April 1992, [1992] ICJ Rep 114, paras 43-45; see also K Roberts, 'Second-Guessing the Security Council: The International Court of Justice and Its Powers of Judicial Review' (1995) 7 Pace International Law Review 281.

200 See eg N Walker, 'Reframing EU Constitutionalism' in J Dunhoff and J Trachtman (eds), Ruling the World? Constitutionalism, International Law, and Global Governance (Cambridge, Cambridge University Press, 2009); JHH Weiler, The Constitution of Europe: Do the New Clothes Have an Emperor? and Other Essays on European Integration (Cambridge, Cambridge University Press, 1999); M Poiares Maduro, We the Court: The European Court of Justice and the European Economic Constitution: A Critical Reading of Article 30 of the EC Treaty (Oxford, Hart Publishing, 1998).

201 Case 26/62 Van Gend en Loos [1962] ECR (English special edition) 00001, para 9.

202 Case 294/83 Les Verts [1986] ECR 01339, para 23.

203 Joined Cases C-402/05 P and C-415/05 P Kadi and Al Barakaat [2008] ECR I-06351, para 285. 
Obligations under the UN Charter were no exception for the ECJ. This is now also more clearly reflected after Lisbon, where provisions have been added ensuring that 'necessary provisions on legal safeguards'204 are to be included in economic sanctions, against both States and natural or legal persons. One should not forget, however, that such a bold stance vis-à-vis the outside world and in favour of fundamental rights is also required due to 'constitutional' pressure 'from below', ie from national constitutional courts that accept EU law's supremacy (and therefore 'constitutionality') only as long as it guarantees these rights to a degree equivalent to the national constitution. ${ }^{205}$ The most recent expression of this pressure can be seen in the German Constitutional Court's Lisbon judgment, stressing that the EU could not be qualified as a 'real', ie nation-state-like constitutional order due to its democratic deficit. 206

Somewhat paradoxically, however, the EU Treaties explicitly acknowledge the special role of the UN but are silent on the WTO. As stipulated in Article 3(5) TEU, the Union's external action is committed to, inter alia, 'free and fair trade' and 'the strict observance and the development of international law, including respect for the principles of the United Nations Charter'. It should be recalled that the EU is a founding member of the WTO with exclusive competence in its matters, and not a member of the UN and with only limited competence in international security matters. Why not say, then, 'free and fair trade in accordance with the principles of the WTO'?207 It must be assumed that the WTO is just another international organisation for the EU and the obligations under WTO just part of general international law.

Similarly, the European Court of Human Rights has defined the ECHR as a 'constitutional instrument of European public order'. ${ }^{208}$ In the Bosphorus case, it pointed to the limits of deference to the European Union. In cases where the protection of the rights enshrined by the Convention was 'manifestly deficient', 'the interest of international cooperation would be outweighed by the Convention's role as a "constitutional instrument of European public order" in the field of human rights. ${ }^{209}$ In more recent cases, however, it showed a wide notion of deference to the United Nations. ${ }^{210}$

\footnotetext{
204 Art 215(3) TFEU.

205 Bundesverfassungsgericht (German Constitutional Court), 2 BvR 197/83 vom 22.10.1986, BVerfGE 73, $339 \mathrm{ff}$.

206 Bundesverfassungsgericht (German Constitutional Court), 2 BvE 2/08 vom 30.6.2009, BVerfGE $123,267 \mathrm{ff}$.

207 The same is true for Art 21(1) TEU on the general provisions of the Union's external action, which also includes a special reference to 'respect for the principles of the United Nations Charter and international law' and mandates the Union to 'promote multilateral solutions to common problems, in particular in the framework of the United Nations'. Note, however, that the 1957 Treaty of Rome contained a reference to the GATT in Art 229, which was later omitted by the Amsterdam Treaty.

208 Loizidou $v$ Turkey (preliminary objections), Series A no 310 (1995) 20 EHRR 99, para 75.

209 Bosphorus v Ireland (2005-VI) 42 EHRR 1, para 156.

210 Behrami and Behrami v France and Saramati v France, Germany and Norway (decision) (2007) 45 EHRR SE10.
} 
What does this mean for the WTO? Trying to fit these different and closelylinked orders into a hierarchical relationship (akin to one found in national constitutional orders) seems impossible. Rather we are faced with what Klabbers calls 'Escherian images', ie legal relationships intertwined like a convoluted web of staircases, where you never know whether you will end up on top or at the bottom. ${ }^{211}$ But this need not be a reason to despair. Arguably, one does not need constitutional hierarchy (or 'top down' or 'hard constitutionalism') in order to have a constitution. Again, the EU serves as a case in point, with its successful structure of 'constitutional pluralism'212 which, if extended to the international sphere, would coincide with the calls for a 'soft' notion of constitutionalism. ${ }^{213}$ Nonetheless, the European experience also shows the limits of any attempt at 'partial constitutionalisation', ie economic integration without any political integration or human rights guarantees, or for having a consolidated internal market without an effective common commercial policy, an environmental policy, a development policy, etc. This also reminds us of the legal importance of coherence between different policy areas, as lack of such puts the 'constitutional' quality of the whole in question. The Lisbon Treaty, with its manifold references to coherence, confirms this. ${ }^{214}$ Therefore, just like the EU and its Member States, the WTO is also to be put, to use the words of the newly-appointed President of the German Constitutional Court, Voßkuhle, into a global 'Ergänzungsverhältnis'215 (a relationship of complementarity) with the other established and aspiring sources of 'constitutional' authority that affect its widening area of operation. In view of the recent case law (see section IV.B.), it appears that the ECJ in fact displays efforts to avoid discord between the EU and WTO legal orders, and therefore actively contributes to such a relationship of complementarity.

In sum, in terms of the CCP as a contributor to the constitutionalisation of the international trading order, we could behold the emergence of the EU as an important international actor, from being founded in the shadow of the GATT to becoming a founding member of the WTO. Ever since, the EU has been an active participant on that stage, and the WTO arguably remains the place where the EU appears most like a unitary, State-like actor. It is thus first and foremost the EU that it 'constitutionalised' further through its WTO membership (which could be called 'reverse constitutionalisation'). This 'actorness' and its legal autonomy

211 J Klabbers, Treaty Conflict and the European Union (Cambridge, Cambridge University Press, 2009), at 173, used in the context of ECJ case law on the UN and the ECHR.

212 See Stone Sweet, above n 194, at 631-39; M Poiares Maduro, 'Contrapunctual Law: Europe's Constitutional Pluralism in Action' in N Walker (ed), Sovereignty in Transition (Oxford, Hart Publishing, 2003); and N Walker, 'The Idea of Constitutional Pluralism' (2002) 65 Modern Law Review 317.

213 de Búrca, 'The European Court of Justice and the International Legal Order after Kadi', above n 181 , at $39-40$.

214 Art 13(1) TEU; Art 16(6), 2nd indent TEU; Art 18(4) TEU; Art 21(3), 2nd indent TEU; Art 26(2) TEU; Art 7 TFEU; Art 334 TFEU.

215 Cited in M Reissenberger, 'Ein unabhängiger Denker mit europäischer Vision', Tagesschau, available at <http://www.tagesschau.de/inland/vosskuhle100.html>. 
also define the way in which it contributes to the 'constitutionalisation' of the WTO. Despite the achievement of establishing a quasi-judicial dispute settlement mechanism with compulsory jurisdiction, the WTO remains to a large extent 'member-driven'. As a result, the EU's courts continue to deny direct effect to WTO law in order to guarantee its trade negotiators the necessary leeway, at times as the expense of prompt compliance with WTO rules as interpreted by the Appellate Body. However, in other instances, the ECJ has shown more subtle ways of ensuring compliance with WTO law at least indicating a relationship of complementarity between the two legal orders and their judicial bodies. In order to develop this relationship further, especially in view of the wider context of the process of 'constitutionalisation', ie in both a vertical (multilevel) and a horizontal (sectoral: trade, security, human rights, environment, etc) way, the EU's internal model of 'constitutional pluralism' and emphasis on coherence continue to serve as a model.

\section{CONCLUSION}

Following this discussion of the trade policy of the EU as an expression of the interconnections between different policies as well as legal orders, the following three basic tenets emerge: First, where there is a common market, there needs to be a common trade policy. Secondly, where there is a common trade policy, foreign policy is right around the corner. Thirdly, the more complicated and intertwined international trade and the connected foreign policy questions become, the greater the need for a framework in which a fair balance between the different goals pursued can be struck and that consequently lends legitimacy to the decision-making process, ie greater need for institutions based on a Wertordnung or, put in legal terms, a 'constitution'.

We could see that the internal market was from the start-and it still is—being shaped by the rules of international trade. Moreover, maintaining an internal market cannot be kept separate from other policy areas, and in many areas the EU has gradually accommodated international requirements, both by changing certain policies and by interpreting its own law in greater harmony with WTO law. But the external trade policy proper cannot be viewed in isolation, as trade also serves as a vehicle for development, which needs to be widely defined in order to be sustainable. That means it needs to respect human rights, good governance as well as environmental norms. In order to attain all these different aims, the EU has put an emphasis on reproducing not only specific norms, but also its entire model of regional integration in other parts of the world. To what degree this will be successful and to what degree this indeed serves as a 'stepping-stone' to multilateralism is still an open question. The 'stepping-stone' metaphor also relates to the 'constitutionalisation' debate, and the argument to what extent the EU can or should be reproduced on a global scale. It is argued here that such a reproduction cannot be properly conceptualised by sticking to the EU-WTO dichotomy. 
Just as the 'constitutionalisation' of the EU cannot be imagined without the ECHR and constitutional traditions of the Member States in mind, so any constitutional claims of the WTO have to be viewed in the wider context. In other words, the WTO system can surely be viewed as an incipient global 'economic constitution', but which would by itself also remain only a partial constitution. In order to capture a more complete picture of an emerging global constitutional order, other constitutional claims have to be taken into account too. The notion of 'constitutional pluralism' allows for such a broadened understanding, making it possible to complete the picture without having to water down or abandon concurrent claims of constitutionality.

In any event, the EU also shows that one need not wait for a 'constitutional moment' to occur in order to discuss the WTO in constitutional terms. Looking to the future, optimism in that respect can be drawn from the fact that both the EU and WTO share strong institutional resilience. The GATT came about and functioned despite the more ambitious International Trade Organisation never seeing the light. European integration proceeded despite failures such as the European Political and Defences Communities. To this one would now have to add the failure of the EU's Constitutional Treaty. This observation is particularly important in terms of 'constitutionalisation', as it shows that one does not need a document called a 'constitution' in order to find oneself in a 'constitutional' system. It is the area of trade in particular that underlines this insight. Instead of ceremonial 'constitutional moments', the background of many 'constitutionalising' moments was much more humble, and related to trade. Just as the direct effect of EU law came forth in a case concerning duties for the importation of urea-formaldehyde by the Van Gend \& Loos company, the Boston Tea Party was an act of resistance against taxes on tea imposed by the British Government. Therefore, to roughly paraphrase Bismarck in a 21 st-century way, ${ }^{216}$ the great questions of the constitution of international trade will not be decided through speeches and lofty 'constitutional moments' but will continue to be decided by such seemingly mundane things as bananas, potatoes, steel plates and shrimps.

216 The original quote was rather bellicose: 'Nicht durch Reden oder Majoritätsbeschlüsse werden die großen Fragen der Zeit entschieden ..., sondern durch Eisen und Blut' ('Not through speeches and majority decisions will the great questions of our times be decided ... but through iron and blood', $\mathrm{tr}$ by author) Cited in W Schüßler, 'Otto von Bismarck, Reden, 1847-1869' in H von Petersdorff (ed), Bismarck: Die gesammelten Werke, Band 10 (Berlin, Otto Stolberg, 1924), at 139-40. 